\begin{tabular}{ll}
\hline \hline MINING AND METALLURGY INSTITUTE BOR & ISSN: 2334-8836 \\
& UDK: 622 \\
\hline \hline
\end{tabular}

\title{
ANALYSIS THE POSIBILITY OF IMPROVING THE ECONOMIC INDICATORS OF EXPLOITATION THE DEPOSIT CEMENTACIJA KRAKU BUGARESKU - ORE FIELD CEROVO***
}

\begin{abstract}
Cementacija - Kraku Bugaresku is a complex of ore bodies in the southeastern part of the deposit Cerovo. It contains a substantial portion of ore with high content of oxides regarding to the total copper in the ore, and with the existing processing technology in the current period, the modest results in metal recovery were achieved. This work, through an analysis, gives a discussion of possible combination of processing using the conventional flotation processing with pyrometallurgical treatment and heap leaching with the hydrometallurgical extraction of metal by $S X-E W$, in terms of the economic viability of such method. This work firstly made a comparison of optimization results of potential open pits in the ore deposit (Whittle Fx), in both cases for the same input techno-economic data. The obtained potential open pits in the optimization process (pit shells) for Revenue Factor 1 (i.e. the selling price of Cu cathode ton of 5,000 \$) are differ from each other by about 8 million tons of ore in favor of the combined processing method and the amount of $\mathrm{Cu}$ in the ore to 16,502.44 $t$, while had grade in the case of method combination is higher for $3.27 \%$. Discounted cash flow is higher by as much as $61.94 \%$, which expressed in monetary units is $47,905,712$ \$.
\end{abstract}

Keywords: heap leaching, $S X-E W$, optimization of open pits, discounted cash flow

\section{INTRODUCTION}

The ore field Kraku Bugaresku (KB) Cementacija is part of a complex of ore deposits at the site Cerovo Mali Krivelj, which is different from the rest of the deposit by the way of origin and type of mineralization. It is a cementation zone of secondary enrichment, and a portion of mineralization belongs to the oxide mineralization (about $40 \%$ of total geological reserves). It consists of the ore bodies Cementacija 1, 2, 3 and 4, out of which Cementacija 3 and 4 are distinguished by content of oxide ore to total reserves. According to the copper content, the complex belongs to the low-grade deposits whose economics of exploitation is very sensitive to some parameters such metal recovery in the process of enrichment, exploitation costs in technological chain from mining to metallurgical treatment, and even the sequence of mining the ore bodies (Push backs) within the cementation zone.

\footnotetext{
* Mining and Metallurgy Institute Bor

** University of Belgrade,Technical Faculty Bor

**** This work is within the Projects of technological development TR33038 "Improving Technology of Exploitation and Processing of Copper Ore with Monitoring the Living and Working Environment in the RTB Bor Group" and TR34004 "The New Production Line for Copper Production by Solvent Extraction of Mine Water", funded by the Ministry of Education, Science and Technological Development of the Republic of Serbia.
} 
Figure 1 shows the analysis of "Grade tonnage" for different cut-off grades, which is the characteristic of the deposit, where the ratio of amount RSULF and ROXD, i.e. amounts of both types of ore deposit.
The most common copper minerals in the upper part of the deposit, the oxidation zone, are cuprite, malachite and azurite, while in the zone of secondary sulphide enrichment, the most common are covellite and chalcocite.

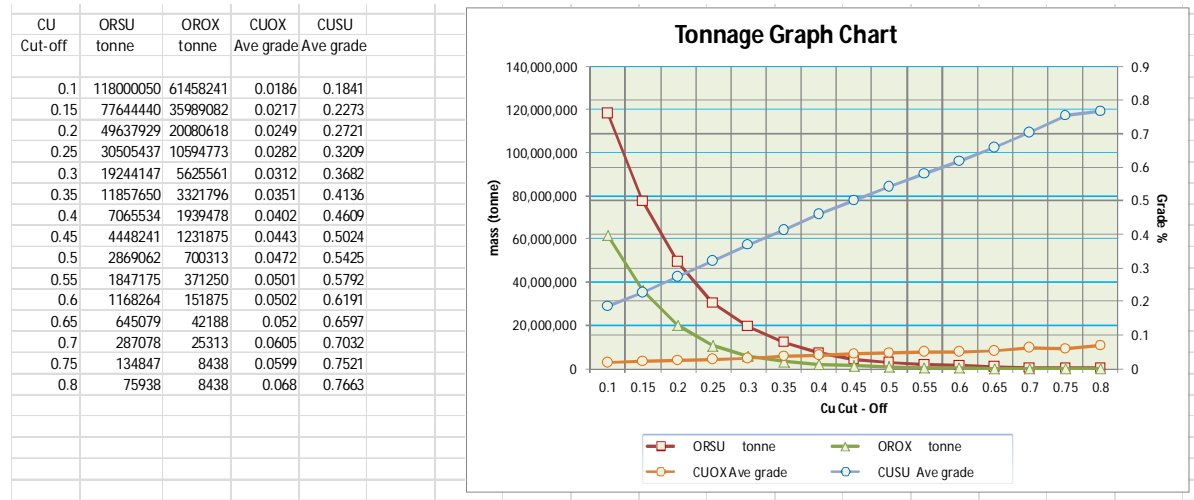

Figure 1 "Grade tonnage" analysis for the copper ore deposit KB - Cementacija for different cut-off grades - Table and Graph

The previous work applied to the mining of deposits Cementacija 1, which consisted of flotation processing of the entire amount of ore above the cut-off grade, without separation of oxide parties of ore from the sulphide, resulted in low copper recovery in the flotation plant, which ranged in the interval between 50 and $70 \%{ }^{1}$. This has certainly a negative impact on the achieved economic results.
Due to these facts it is important to review and analyze the possibilities of increasing NPV, ie Cashflow in the exploitation of the complex ore bodies.

At the present level of technological development of exploitation and recovery of metals from oxide and sulphide ores, the importance is recently given to leaching and solvent extraction of leaching solutions from oxide ore, and even from sulphide ore (or concentrate).

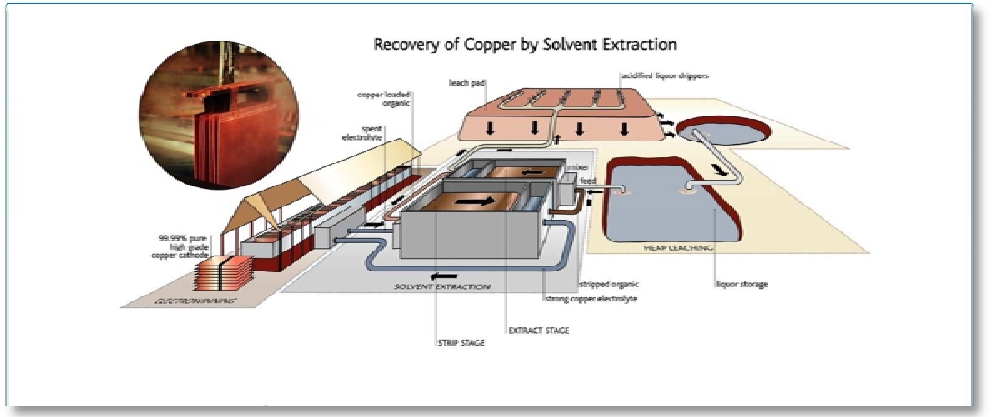

Figure 2 Process Flow Diagram - heap leaching, solvent extraction and electro wining ${ }^{1}$ In the official Documents (Annual Technical Reports on Production of RBB, 1993. -2000.), the Production
Results are not Presented Credible 


\section{ANALYSIS IN SOFTWARE FOR STRATEGIC PLANNING WHITTLE FX}

The input techno-economic data for carried out analysis in software for strategic planning Whittle $\mathrm{Fx}$, for scenario 1 and 2, i.e. flotation of sulphide and oxide ores together, without selective mining with additional method of enrichment heap leaching of the ore with more than $10 \%$ of oxides, are the following:

Table 1 Input techno-economic parameters of exploitation for the optimization process (input)

\begin{tabular}{|c|c|c|}
\hline Parameter & Unit & Values \\
\hline Capacity of excavation - excavations & t/year & 12Mt from 3.year17 Mt \\
\hline $\begin{array}{l}\text { Capacity of flotation processing - Sul- } \\
\text { phide ore with max. } 10 \% \text { oxide }\end{array}$ & t/year & 2.5Mt from 3. year $5.5 \mathrm{Mt}$ \\
\hline $\begin{array}{l}\text { Capacity of heap leaching - Oxide ore } \\
\text { with over } 10 \% \text { oxide content }\end{array}$ & t/year & $2.5 \mathrm{Mt}$ \\
\hline Copper price & $\$ /$ cathode & $5,000.00$ \\
\hline Gold price & $\$ / \mathrm{kg}$ & $40,000.00$ \\
\hline Silver price & $\$ / \mathrm{kg}$ & 500.00 \\
\hline Excavation costs & $\$ / \mathrm{t}$ & 2.3 \\
\hline Flotation processing costs & $\$ / \mathrm{t}$ & 4.00 \\
\hline Heap leaching costs & $\$ / t$ ore & 1.00 \\
\hline Metallurgical copper treatment costs & $\$ /$ cathode & 450.00 \\
\hline Metallurgical gold treatment costs & $\$ / \mathrm{kg}$ & 150.00 \\
\hline Metallurgical silver treatment costs & $\$ / \mathrm{kg}$ & 15.00 \\
\hline $\begin{array}{l}\text { Hydrometallurgical treatment costs } \\
\text { (SXEW) }\end{array}$ & $\$ / t$ cathode & 100.0 \\
\hline $\begin{array}{l}\text { Initial capital costs of leaching and } \\
\text { SXEW }\end{array}$ & $\$$ & $20,000,000$ \\
\hline $\begin{array}{l}\text { Total copper recovery (flotation and } \\
\text { metal.) }\end{array}$ & $\%$ & 0.788 \\
\hline Total gold recovery (flotation and metal.) & $\%$ & 0.50 \\
\hline Silver recovery (flotation and metal.) & $\%$ & 0.40 \\
\hline $\begin{array}{l}\text { Copper recovery from oxide ore with } \\
\text { over } 10 \% \text { oxide content }\end{array}$ & $\%$ & 0.54 \\
\hline Discount rate & $\%$ & 10.0 \\
\hline
\end{tabular}


Analysis $^{2}$ was carried out for 3 scenarios, as follows:

1. Scenario 1 - processing method marked as "MILL", i.e. flotation ROXD and RSULF, i.e. two types of ore;

2. Scenario 2- method "MILL" for ore with $>10 \%$ oxide, and method "LEAC" for ore with content > $10 \%$ oxide, wherein the leaching capacity is not limited;

3. Scenario 3 - same as Scenario 2, but with limited capacity of leaching to 2,500,000 t, and with the use of two types of stockpiles for ore less than $10 \%$ oxide ore and over $10 \%$ oxide (SP1 and SP2). Stockpiles were used as a "buffer" for addition of design capacity both in the flotation and leaching.

In further analysis for Scenarios 1 and 2 , the results of optimization are presented in the tables type Pit Pit By Garph, i.e. the open pits from optimization with calcula- ted cash flow and discounted cash flow for each of a set of nested open pit mines. Economic indicators are calculated for three possible cases - the Best Case, Worst Case, and Specific Case, i.e. for the mining bench by bench, and using pushbacks in mining. A key for the evaluation and selection of the optimal pit on the criterion of the optimal profit is discounted cash flow best case. This means that the selected pit (Final pit) is excavated in stages (Push backs).

In all three cases, a mining schedule is designed and calculated for mine life of selected open pit per the above criteria with the appropriate graphical views. Also, the calculated amounts per type of ore (as Rock Type) are presented in tables, with lower and higher oxide contents, or the realized capacities for the method "MILL" and method "LEAC" in Scenario 3 - with additional calculated amounts of ore that go to the stockpiles and from there into the process.

\footnotetext{
${ }^{2}$ Beside the above given input data, the block model of deposit, so called "mod" file, is exported into software Whittle. In designing the mentioned "mod" file in the basic software, in this case Gemcom, the terrain topography is used, i.e. current mining lay out. In the case of this analysis, the mining lay out is at 10.08.2001, before reactivation of open pit, because the analysis was not carried out as a part of the Study or Project, but with the aim to point out the possibilities for increasing the economic effects of production, also initiating the important explorations aimed to extraction of $\mathrm{Cu}$ by hydrometallurgical method.
} 


\section{SCENARIO 1 One Type of Processing MILL (Flotation) of Sulphide and Oxide Ore Together}

Table 2 Tabular presentation of optimization results per Scenario 1 with calculated cash flow

\begin{tabular}{|c|c|c|c|c|c|c|c|c|c|}
\hline & & & \multicolumn{7}{|c|}{ PIT BY PIT GRAPH - SCENARIO 1} \\
\hline & & & & & & & & & \\
\hline & Revenue & & & & & & & & \\
\hline & factor & Open pit & Open pit & Open pit & & & Mine & Mine & Mine \\
\hline & for & cashflow & cashflow & cashflow & tonne & Waste & life & life & life \\
\hline Final & final & best & specified & worst & input & best & years & years & years \\
\hline pit & pit & $\$$ disc & $\$$ disc & $\$$ disc & best & tonne & best & specified & worst \\
\hline 1 & 0.3 & $1,257,649$ & $\begin{array}{ll}9 & 1,257,649\end{array}$ & $\begin{array}{l}9 \\
1,257,649\end{array}$ & 64,520 & 9,407 & 0.03 & 0.03 & 0.03 \\
\hline 2 & 0.3 & $2,340,019$ & $\begin{array}{ll}9 & 2,340,019\end{array}$ & $9 \quad 2,340,019$ & 127,897 & 9,971 & 0.05 & 0.05 & 0.05 \\
\hline 3 & 0.3 & $3,265,188$ & $\begin{array}{ll}8 & 3,265,188\end{array}$ & 3) $3,265,188$ & 188,088 & 10,150 & 0.08 & 0.08 & 0.08 \\
\hline 4 & 0.3 & $4,415,908$ & $\begin{array}{ll}8 & 4,415,908\end{array}$ & $\begin{array}{ll}3 & 4,415,908\end{array}$ & 272,142 & 14,544 & 0.11 & 0.11 & 0.11 \\
\hline 5 & 0. & $5,121,194$ & $\begin{array}{ll}4 & 5,121,194\end{array}$ & $45,121,194$ & 326,594 & 28,340 & 0.13 & 0.13 & 0.13 \\
\hline 6 & 0.4 & $6,782,948$ & $\begin{array}{ll}8 & 6,782,948\end{array}$ & $\begin{array}{ll}3 & 6,782,948\end{array}$ & 475,371 & 39,226 & 0.19 & 0.19 & 0.19 \\
\hline 7 & 0.4 & $8,622,922$ & $28,622,922$ & $28,622,922$ & 654,558 & 64,086 & 0.26 & 0.26 & 0.26 \\
\hline 8 & 0.4 & $\begin{array}{ll}46 & 10,525,070\end{array}$ & $10,525,070$ & $10,525,070$ & 868,580 & 85,685 & 0.35 & 0.35 & 0.35 \\
\hline 9 & 0.4 & $18 \quad 13,053,414$ & $13,053,414$ & $413,053,414$ & $1,188,709$ & 111,857 & 0.48 & 0.48 & 0.48 \\
\hline 10 & 0. & $.5 \quad 15,071,636$ & $15,071,636$ & $15,071,636$ & $1,480,565$ & 120,560 & 0.59 & 0.59 & .59 \\
\hline 11 & 0.5 & $\begin{array}{ll}52 & 15,737,824\end{array}$ & $15,737,824$ & $45,737,824$ & $1,589,257$ & 128,947 & 0.64 & 0.64 & 0.64 \\
\hline 12 & 0.5 & $54 \quad 18,383,286$ & $18,383,286$ & $18,383,286$ & $2,040,985$ & 229,016 & 0.82 & 0.82 & 0.82 \\
\hline 13 & 0.5 & $\begin{array}{ll}56 & 20,388,697\end{array}$ & $20,388,697$ & $720,388,697$ & $2,429,329$ & 299,806 & 0.97 & 0.97 & 0.97 \\
\hline 14 & 0. & $\begin{array}{ll}58 & 21,534,215\end{array}$ & $21,532,415$ & $21,532,415$ & $2,663,808$ & 335,688 & 1.07 & 1.07 & 1.07 \\
\hline 15 & & $\begin{array}{ll}6 & 48,788,934\end{array}$ & + 47,538,914 & $47,538,914$ & $7,875,043$ & $5,582,314$ & .52 & 2.52 & .52 \\
\hline 16 & 0.6 & $52 \quad 55,146,867$ & $53,508,008$ & $53,508,008$ & $9,599,654$ & $6,485,167$ & 2.84 & 2.84 & 2.84 \\
\hline 17 & 0.6 & $54 \quad 63,570,562$ & $60,902,078$ & 8 $60,902,078$ & $11,991,784$ & $7,986,686$ & 3.27 & 3.27 & 3.27 \\
\hline 18 & 0.6 & $\begin{array}{ll}56 & 67,546,940\end{array}$ & $64,308,942$ & $264,308,942$ & $13,194,047$ & $8,727,104$ & 3.49 & 3.49 & 3.49 \\
\hline 19 & 0.6 & $\begin{array}{ll}58 & 76,251,473\end{array}$ & $71,761,565$ & $71,761,565$ & $16,394,020$ & $10,505,786$ & 4.07 & 4.07 & 4.07 \\
\hline 20 & 0. & $\begin{array}{ll}.7 & 79,816,489\end{array}$ & $74,837,962$ & $274,837,962$ & $17,911,544$ & $11,034,033$ & 4.35 & 4.35 & 4.35 \\
\hline 21 & 0.7 & $\begin{array}{ll}72 & 84,77\end{array}$ & $78,120,000$ & $78,120,000$ & $20,275,932$ & $12,509,270$ & 4.78 & 4.78 & 4.78 \\
\hline 22 & 0.7 & $\begin{array}{ll}74 & 87,297,954\end{array}$ & 79,729 & $79,729,295$ & $21,721,280$ & $13,173,614$ & 5.04 & 5.04 & 5.04 \\
\hline 23 & 0.7 & $\begin{array}{ll}76 & 99,408,000\end{array}$ & $82,884,123$ & 3 $82,884,123$ & $28,647,492$ & $19,642,382$ & 6.30 & 6.55 & 6.55 \\
\hline 24 & 0.7 & $78 \quad 102,648,142$ & $83,151,343$ & 3 $83,151,343$ & $31,079,978$ & $21,409,083$ & 6.74 & 7.05 & 7.05 \\
\hline 25 & 0. & 8105 & 82,93 & 3 $82,932,523$ & $33,864,262$ & 24 & 7.25 & 7.62 & 7.62 \\
\hline 26 & 0.8 & $32 \quad 107,796,516$ & $83,166,000$ & $83,166,000$ & $36,026,740$ & $25,479,248$ & 7.64 & 8.02 & 8.02 \\
\hline 27 & 0.8 & $34 \quad 109,864,961$ & $82,857,682$ & $82,857,682$ & $38,690,541$ & $27,906,217$ & 8.13 & 8.52 & 8.52 \\
\hline 28 & 0.8 & $36 \quad 112,055,441$ & $81,155,078$ & $81,155,078$ & $41,754,095$ & $31,007,667$ & 8.68 & 9.10 & 9.10 \\
\hline 29 & 0.8 & $38 \quad 113,121,606$ & $80,039,265$ & $80,039,265$ & $43,695,298$ & $33,065,173$ & 9.04 & 9.46 & 9.46 \\
\hline 30 & 0. & $9115,083,888$ & $75,541,273$ & $75,541,273$ & $48,341,430$ & $37,235,782$ & 9.88 & 10.32 & 10.32 \\
\hline 31 & 0.9 & $2 \quad 115,9$ & 71,5 & $71,519,775$ & $50,942,253$ & 40, & 10.35 & 0.89 & 10.89 \\
\hline 32 & 0.9 & $34 \quad 116$ & 69,4 & $69,437,935$ & $52,691,741$ & 42 & 67 & 1.24 & 1.24 \\
\hline 33 & 9 & 66116,5 & $67,166,852$ & $67,166,852$ & $54,558,738$ & $44,257,231$ & 11.01 & 11.62 & 11.62 \\
\hline 34 & 0.9 & $88 \quad 116,812,522$ & $63,546,156$ & $63,546,156$ & $56,940,722$ & $47,520,092$ & 11.44 & 12.10 & 12.10 \\
\hline 35 & & & & & $57,462,570$ & & 54 & 12.20 & 12.20 \\
\hline 36 & .0 & $\begin{array}{ll}71 & 116,733,132\end{array}$ & 60,24 & $60,247,593$ & $59,523,326$ & $50,336,326$ & 11.91 & 12.60 & 12.60 \\
\hline 37 & 0 & & 57,0 & 3 $57,088,898$ & $61,004,701$ & $52,645,714$ & 12.18 & 12.91 & 12.91 \\
\hline 38 & I & 06116 & 53,5 & 3,340 & $62,679,665$ & 55 & 12.49 & 13.27 & 13.27 \\
\hline 39 & 1.0 & $88 \quad 116,104,201$ & 52,6 & + 52,612,974 & $63,285,683$ & $56,807,448$ & 12.60 & 13.38 & 13.38 \\
\hline 40 & & 1115,8 & & 51,2 & $63,973,933$ & $57,909,775$ & 12.72 & 13.51 & 13.51 \\
\hline 41 & 1.1 & $12 \quad 114,77$ & 41,51 & $41,519,881$ & $67,492,199$ & $62,846,779$ & 13.36 & 14.34 & 14.34 \\
\hline 42 & 1 & $14 \quad 114,2$ & +37,924,212 & . $37,924,212$ & $68,822,070$ & $65,024,645$ & 13.60 & 14.65 & 14.65 \\
\hline 43 & & & & 37, & $69,049,326$ & & 13.65 & 14.69 & 14.69 \\
\hline 44 & 1.1 & $18 \quad 113,547,212$ & $35,394,348$ & $35,394,348$ & $70,505,451$ & $68,088,287$ & 13.91 & 14.96 & 14.96 \\
\hline 45 & 1. & & 34,216 & & & & 14.06 & 15.11 & 15.11 \\
\hline 46 & 72 & & 31 & 31 & 72,26 & & 14.23 & 15.34 & 5.34 \\
\hline 47 & 2 & $24 \quad 112,393,820$ & $29,204,421$ & $29,204,421$ & $72,820,099$ & $72,285,894$ & 14.33 & 15.48 & 15.48 \\
\hline 48 & & & $18,407,558$ & $18,407,558$ & $75,656,596$ & $79,276,775$ & 14.86 & 16.25 & 16.25 \\
\hline 49 & 1.2 & $28 \quad 109,992,003$ & $16,490,497$ & $16,490,497$ & $76,759,211$ & $81,937,428$ & 15.15 & 16.46 & 16.46 \\
\hline 50 & 1. & & & & & & 15.43 & 16.80 & 16.80 \\
\hline 51 & 1 & 3210 & 10,9 & $10,951,659$ & $78,476,259$ & $85,430,456$ & 15.46 & 16.83 & 6.83 \\
\hline 52 & 3 & $34 \quad 108,604,954$ & $9,631,895$ & $9,631,895$ & $78,947,606$ & $86,580,421$ & 15.54 & 16.93 & 16.93 \\
\hline & & & & & & & 15.57 & 16.96 & \\
\hline 54 & 1.3 & $38 \quad 107,646,094$ & $6,399,243$ & 3 $6,399,243$ & $80,168,057$ & $89,781,653$ & 15.77 & 17.17 & 17.17 \\
\hline 55 & 1. & $4106,959,546$ & $4,034,446$ & $4,034,446$ & $81,102,333$ & $92,015,091$ & 15.94 & 17.35 & 17.35 \\
\hline 56 & 1.4 & 704 & $3,213,701$ & $3,213,701$ & $81,439,009$ & $92,833,624$ & 16.00 & 17.41 & 17.41 \\
\hline 57 & 1.4 & $44 \quad 106,461,667$ & $2,659,448$ & $2,659,448$ & $81,716,767$ & $93,627,441$ & 16.06 & 17.47 & 17.47 \\
\hline & & $46 \quad 106$ & $1,975,632$ & $1,975,632$ & $82,087,111$ & 221,529 & 16.14 & 17.53 & 17.53 \\
\hline 59 & 1.4 & $48 \quad 106,087,512$ & $1,742,133$ & $1,742,133$ & $82,154,446$ & $94,741,304$ & 16.15 & 17.55 & 17.55 \\
\hline 60 & 1. & $\begin{array}{ll}.5 & 105.680 .501\end{array}$ & 702.770 & 702.770 & 82.533 .207 & 96.158 .579 & 16.25 & 17.62 & 17.62 \\
\hline
\end{tabular}




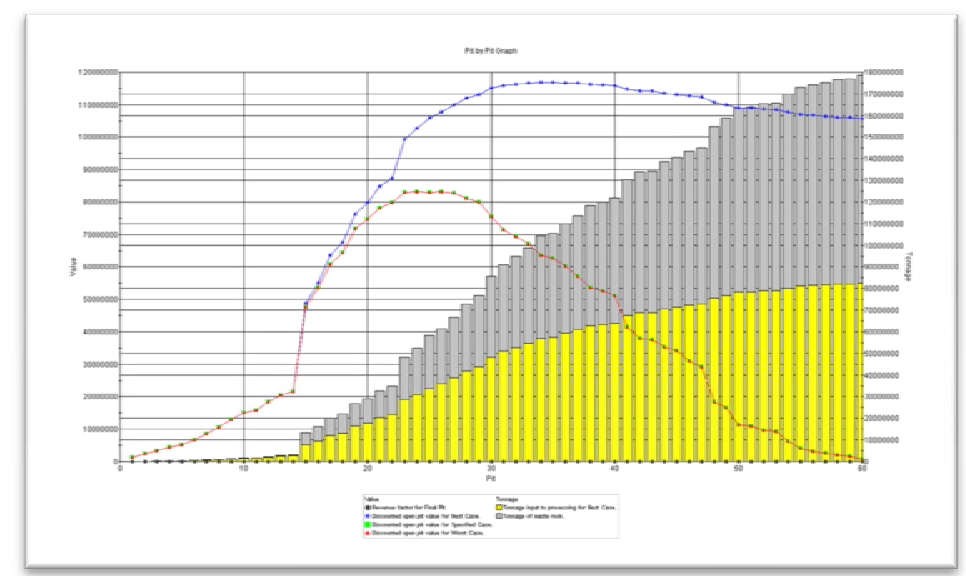

Figure 3 Pit by Pit graph - Graph of optimization per Scenario 1

Table 3 Mining dynamics per Scenario 1

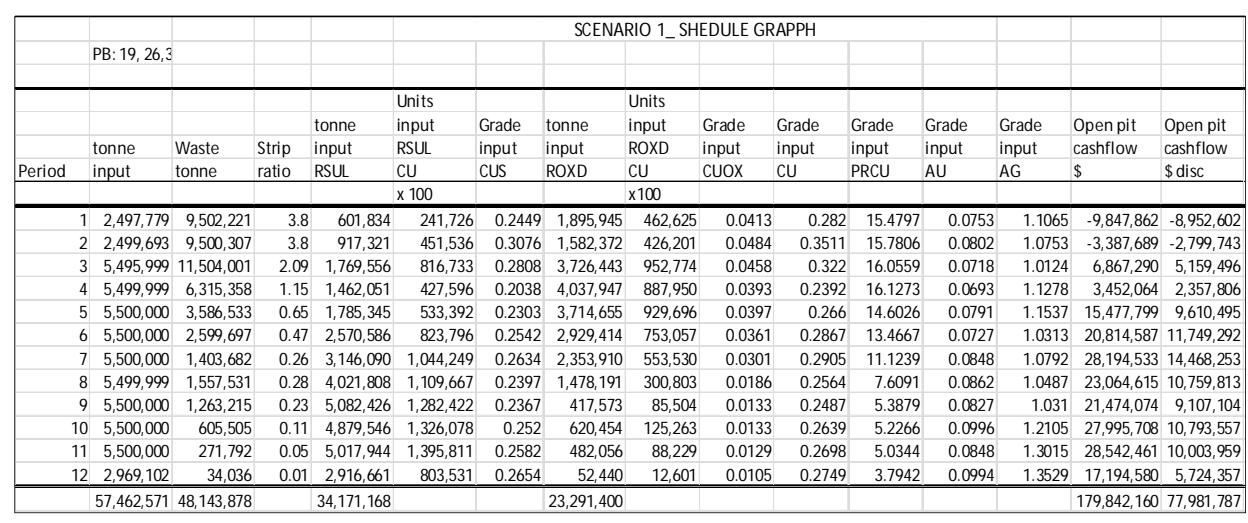

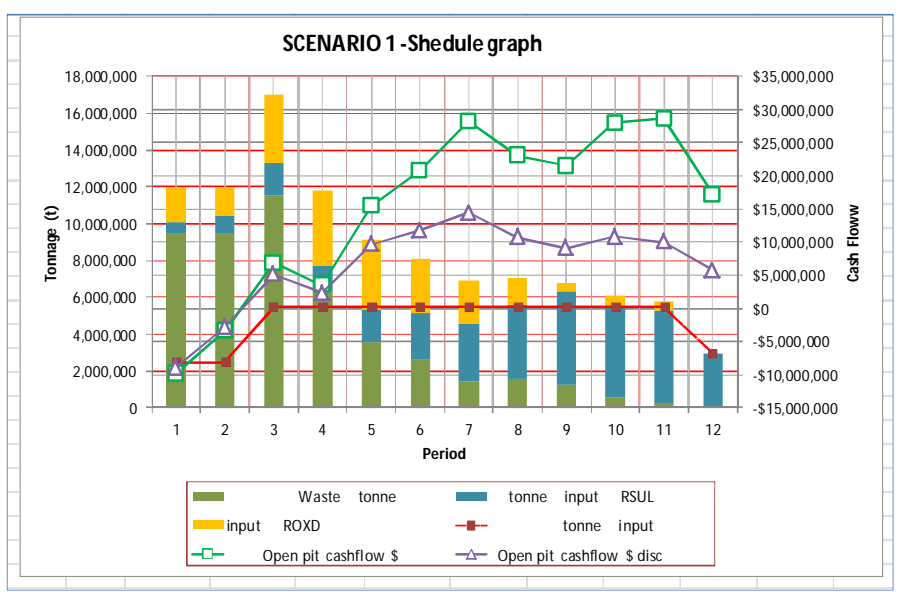

Figure 4 Graphical view of mining dynamics per Scenario 1, with one processing method-MILL; total ore amounts without selective mining go to the flotation processing and concentrate to the pyrometallurgical method 


\section{SCENARIO 2 Two Types of Processing MILL (Flotation) and HEAP LEACHING}

Table 4 Tabular presentation of optimization results per Scenario with calculated cash flow

\begin{tabular}{|c|c|c|c|c|c|c|c|c|c|c|c|}
\hline & \multicolumn{8}{|c|}{ PIT BY PIT GRAPH - SCENARIO 2} & \multirow{3}{*}{\multicolumn{2}{|c|}{$\begin{array}{l}\text { Internal } \\
\text { rate of }\end{array}$}} & \multirow[b]{2}{*}{ Internal } \\
\hline & \multirow{2}{*}{$\begin{array}{l}\text { Revenue } \\
\text { factor }\end{array}$} & & & & & & & & & & \\
\hline & & Open pit & Open pit & Open pit & & & Mine & Mine & & & rate of \\
\hline & for & cashflow c & cashflow & cashflow & tonne & Waste & life & life & life & return & return \\
\hline Final & final & best & specified & worst & input & best & years & years & years & best & worst \\
\hline pit & pit & $\$$ disc & $\$$ disc & $\$$ disc & best & tonne & best & specified & worst & $\%$ & $\%$ \\
\hline 1 & & $0.3-19,672,238$ & $\begin{array}{ll}8 & -19,672,238\end{array}$ & $\begin{array}{ll} & -19,672,238 \\
\end{array}$ & 26,916 & 67 & 0.00 & 0.00 & 0.00 & 0 & 0 \\
\hline 2 & 0.3 & $32-18,172,452$ & $\begin{array}{lr}2 & -18,172,452\end{array}$ & $-18,172,452$ & 117,064 & 11,192 & 0.03 & 0.03 & 0.03 & 0 & 0 \\
\hline 3 & 0.3 & $34-16,598,225$ & $\begin{array}{ll}5 & -16,598,225\end{array}$ & $-16,598,225$ & 236,298 & 14,400 & 0.05 & 0.05 & 0.05 & 0 & 0 \\
\hline 4 & 0.3 & $36-15,206,239$ & $\begin{array}{l}9 \\
9\end{array}$ & $-15,206,239$ & 356,166 & 17,900 & 0.08 & 0.08 & 0.08 & 0 & 0 \\
\hline 5 & 0.3 & $38-13,815,237$ & $\begin{array}{ll}7 & -13,815,237\end{array}$ & $-13,815,237$ & 471,549 & 24,595 & 0.11 & 0.11 & 0.11 & 0 & 0 \\
\hline 6 & & 0.4 - $-12,477,700$ & $0 \quad-12,477,700$ & $-12,477,700$ & 623,194 & 47,353 & 0.13 & 0.13 & 0.13 & 0 & 0 \\
\hline 7 & 0.4 & $42-10,006,388$ & $\begin{array}{ll}8 & -10,006,388\end{array}$ & $\begin{array}{l}3 \\
-10,006,388\end{array}$ & 879,677 & 89,393 & 0.20 & 0.20 & 0.20 & 0 & 0 \\
\hline 8 & 0.4 & 244,677 & 244,677 & 244,677 & $2,221,015$ & 757,403 & 0.29 & 0.29 & 0.29 & 4.03 & 4.03 \\
\hline 9 & 0.4 & $\begin{array}{ll}46 \quad 2,673,733\end{array}$ & $2,673,733$ & $2,673,733$ & $2,552,183$ & 830,394 & 0.36 & 0.36 & 0.36 & 17.29 & 17.29 \\
\hline 10 & 0.4 & $\begin{array}{ll}48 & 8,658,819\end{array}$ & $8,658,819$ & $8,658,819$ & $3,431,323$ & $1,262,659$ & 0.48 & 0.48 & 0.48 & 50.03 & 50.03 \\
\hline 11 & & $\begin{array}{ll}0.5 & 17,861,713\end{array}$ & $17,861,713$ & $17,861,713$ & $5,020,490$ & $2,005,231$ & 0.69 & 0.69 & 0.69 & 102.2 & 102.2 \\
\hline 12 & 0.5 & $\begin{array}{ll}52 & 56,166,769\end{array}$ & $54,806,665$ & $54,806,665$ & 5. $11,373,660$ & $7,933,596$ & 2.07 & 2.19 & 2.19 & 174.16 & 136.69 \\
\hline 13 & 0.5 & $\begin{array}{ll}54 & 72,345,544\end{array}$ & $68,906,902$ & $68,906,902$ & $14,459,921$ & $10,464,136$ & 2.36 & 2.49 & 2.49 & 183.73 & 116.43 \\
\hline 14 & 0.5 & $\begin{array}{ll}56 & 78,651,502\end{array}$ & $74,683,218$ & $74,683,218$ & $\begin{array}{ll}3 & 15,955,469\end{array}$ & $11,180,073$ & 2.49 & 2.64 & 2.64 & 187.33 & $\begin{array}{ll}3 & 116.22 \\
\end{array}$ \\
\hline 15 & 0.5 & $\begin{array}{ll}58 & 89,657,379\end{array}$ & $83,964,252$ & $83,964,252$ & $18,628,312$ & $12,656,334$ & 2.74 & 2.97 & 2.97 & 193.51 & $1 \quad 112.76$ \\
\hline 16 & & D.6 $94,177,326$ & $88,262,713$ & $88,262,713$ & $\begin{array}{ll}3 & 19,906,020\end{array}$ & $13,491,902$ & 2.86 & 3.11 & 3.11 & 196.05 & 110.79 \\
\hline 17 & 0.6 & $62102,041,906$ & $94,967,147$ & $94,967,147$ & $7 \quad 22,306,910$ & $14,818,353$ & 3.20 & 3.44 & 3.44 & 198.55 & 103.31 \\
\hline 18 & 0.6 & $64 \quad 107,825,197$ & $99,135,151$ & $99,135,151$ & $1 \quad 24,190,047$ & $\begin{array}{l}7 \quad 15,786,074\end{array}$ & 3.44 & 3.72 & 3.72 & 199.57 & 98.3 \\
\hline 19 & 0.6 & 66 115,263,766 & 5 $104,855,424$ & $104,855,424$ & $4 \quad 26,963,760$ & $17,384,509$ & 3.78 & 4.11 & 4.11 & 200.93 & 92.92 \\
\hline 20 & 0.6 & $68 \quad 119,827,401$ & $109,467,857$ & $108,368,981$ & 1. $28,858,724$ & $4 \quad 18,643,233$ & 4.03 & 4.36 & 4.39 & 201.72 & 87.95 \\
\hline 21 & & $0.7131,018,438$ & 3. $119,070,774$ & $114,123,936$ & $6 \quad 33,311,000$ & $23,050,589$ & 4.59 & 4.92 & 5.07 & 202.39 & 74.82 \\
\hline 22 & 0.7 & $72133,849,985$ & 5. $\quad 121,691,295$ & $115,646,776$ & 6 $\quad 34,870,282$ & $24,119,422$ & 4.77 & 5.10 & 5.35 & 202.58 & 71.9 \\
\hline 23 & 0.7 & $74 \quad 146,289,750$ & $134,152,102$ & $117,198,533$ & 3 $42,640,316$ & $31,908,409$ & 5.74 & 5.84 & 6.58 & 202.61 & 54.6 \\
\hline 24 & 0.7 & $76 \quad 151,869,938$ & 3. $\quad 139,491,522$ & $117,668,350$ & $46,568,407$ & $35,916,783$ & 6.18 & 6.24 & 7.17 & 202.7 & 49.49 \\
\hline 25 & 0.7 & $78 \quad 153,176,720$ & $\quad 140,648,407$ & $117,997,340$ & $47,586,853$ & $36,658,979$ & 6.32 & 6.38 & 7.36 & 202.71 & 48.83 \\
\hline 26 & & $0.8155,346,218$ & $3 \quad 141,567,411$ & $116,920,205$ & $49,572,609$ & $38,908,109$ & 6.48 & 6.75 & 7.70 & 202.73 & 46.22 \\
\hline 27 & 0.8 & $82 \quad 157,052,532$ & $143,038,162$ & $116,146,307$ & 7. $51,466,413$ & $40,623,250$ & 6.70 & 6.96 & 8.01 & 202.75 & 44.61 \\
\hline 28 & 0.8 & $84 \quad 158,467,534$ & $144,384,440$ & $115,089,056$ & $6 \quad 53,107,709$ & $42,556,953$ & 6.92 & 7.18 & 8.32 & 202.76 & 42.8 \\
\hline 29 & 0.8 & $86 \quad 159,647,264$ & $\begin{array}{r}145,337,729 \\
\end{array}$ & $114,353,244$ & $4 \quad 54,648,002$ & $44,289,647$ & 7.13 & 7.40 & 8.59 & 202.76 & 41.68 \\
\hline 30 & 0.8 & $88160,916,422$ & 2. $146,339,541$ & $112,147,672$ & $2 \quad 56,769,062$ & $46,725,984$ & 7.39 & 7.65 & 8.95 & 202.76 & 39.53 \\
\hline 31 & & $.9161,913,154$ & $\quad 146,964,713$ & $109,851,681$ & 1. $58,780,703$ & $49,642,105$ & 7.63 & 7.89 & 9.28 & 202.77 & 37.45 \\
\hline 32 & 0.9 & $92 \quad 162,816,991$ & $147,314,004$ & $104,105,169$ & $\begin{array}{l}91,768,704 \\
\end{array}$ & $53,527,893$ & 8.03 & 8.11 & 9.82 & 202.77 & 33.85 \\
\hline 33 & 0.9 & $94 \quad 163,095,472$ & $\quad 147,660,882$ & $103,368,020$ & $62,694,563$ & $54,471,675$ & 8.16 & 8.24 & 9.98 & 202.77 & 33.5 \\
\hline 34 & 0.9 & $96163,321,340$ & $147,887,443$ & $101,824,917$ & 7. $63,822,428$ & $56,193,108$ & 8.31 & 8.39 & 10.19 & 202.77 & 32.62 \\
\hline 35 & 0.9 & \begin{tabular}{|l|l|}
98 & $163,417,237$ \\
\end{tabular} & $147,538,011$ & $98,291,386$ & $65,463,725$ & $58,731,018$ & 8.53 & 8.61 & 10.49 & 202.77[ & 30.92 \\
\hline 36 & 1.0 & \begin{tabular}{|l|l|}
00 & $163,413,866$ \\
\end{tabular} & $147,208,895$ & $95,534,405$ & $66,860,931$ & $61,005,204$ & 8.75 & 8.81 & 10.74 & 202.77 & 29.78 \\
\hline 37 & 1.0 & $02163,350,325$ & $146,984,292$ & $93,855,435$ & $67,618,452$ & $62,402,200$ & 8.88 & 8.92 & 10.90 & 202.77 & 29.17 \\
\hline 38 & 1.0 & $04 \quad 162,990,167$ & $146,391,624$ & $88,142,664$ & 4. $69,621,676$ & $66,530,279$ & 9.24 & 9.10 & 11.32 & 202.77 & 26.95 \\
\hline 39 & 1.0 & $06 \quad 162,687,631$ & $146,011,943$ & $84,136,112$ & $70,825,293$ & $69,012,059$ & 9.45 & 9.22 & 11.61 & 202.77 & 25.54 \\
\hline 40 & 1.0 & $08162,418,596$ & $145,687,328$ & $81,941,941$ & 1. $71,675,400$ & $70,757,066$ & 9.61 & 9.32 & 11.78 & 202.77 & 24.91 \\
\hline 41 & & $1.1161,958,663$ & 3. $145,239,954$ & $\begin{array}{l}77,022,384 \\
\end{array}$ & $4 \quad 73,114,691$ & $73,794,528$ & 9.87 & 9.43 & 12.01 & 202.77 & 23.38 \\
\hline 42 & 1.1 & $12 \quad 161,715,486$ & f $144,974,952$ & $76,337,965$ & 5 $73,754,376$ & $74,761,151$ & 9.97 & 9.54 & 12.12 & 202.77 & 23.23 \\
\hline 43 & & $14 \quad 161,282,789$ & $144,524,440$ & $74,139,095$ & 5 $74,713,903$ & $76,282,487$ & 10.12 & 9.66 & 12.28 & 202.77 & 22.64 \\
\hline 44 & 1.1 & $16 \quad 160,393,985$ & $143,478,731$ & $70,610,743$ & B $76,271,030$ & $79,628,190$ & 10.40 & 9.93 & 12.63 & 202.77 & 21.87 \\
\hline 45 & 1.1 & $18 \quad 160,009,540$ & $143,005,599$ & $68,802,935$ & $76,927,549$ & $80,809,058$ & 10.51 & 10.05 & 12.77 & 202.77 & 21.46 \\
\hline 46 & & $1.2159,750,944$ & $142,701,727$ & $67,614,646$ & $77,306,309$ & $81,529,923$ & 10.57 & 10.12 & 12.87 & 202.77 & 21.21 \\
\hline 47 & 1.2 & $22 \quad 159,499,447$ & $142,341,707$ & $66,256,070$ & $77,676,653$ & $82,319,161$ & 10.64 & 10.17 & 12.96 & 202.77 & 20.91 \\
\hline 48 & 1.2 & $24 \quad 159,295,897$ & $142,113,953$ & $65,799,438$ & \begin{tabular}{|l}
$77,945,994$ \\
\end{tabular} & $82,837,707$ & 10.69 & 10.22 & 13.02 & 202.77 & 20.84 \\
\hline 49 & 1.2 & $26158,015,015$ & $139,922,517$ & $62,328,616$ & $79,410,535$ & $86,639,495$ & 11.00 & 10.79 & 13.35 & 202.77 & 20.18 \\
\hline 50 & 1.2 & $28 \quad 157,863,368$ & $139,693,840$ & $61,865,282$ & $\begin{array}{l}79,595,707 \\
\end{array}$ & $86,985,252$ & 11.03 & 10.85 & 13.39 & 202.77 & 20.09 \\
\hline 51 & & $1.3 \quad 157,367,328$ & $139,021,808$ & $60,337,557$ & $80,134,389$ & $88,212,094$ & 11.13 & 11.01 & 13.52 & 202.77 & 19.79 \\
\hline 52 & 1.3 & $32157,072,032$ & $138,672,839$ & $59,388,993$ & $80,428,981$ & $88,960,379$ & 11.19 & 11.11 & 13.59 & 202.77 & 19.61 \\
\hline 53 & 1.3 & $34 \quad 156,925,269$ & $138,858,175$ & $58,867,463$ & $80,580,485$ & $89,306,146$ & 11.22 & 11.15 & 13.63 & 202.77 & 19.51 \\
\hline 54 & 1.3 & $36 \quad 155,676,400$ & $136,824,618$ & $55,643,325$ & $81,582,097$ & $92,525,863$ & 11.47 & 11.45 & 13.85 & 202.77 & 18.95 \\
\hline 55 & 1.3 & 38 155,395,291 & $136,336,916$ & $54,535,636$ & $81,851,438$ & $93,245,125$ & 11.53 & 11.51 & 13.91 & 202.77 & 18.73 \\
\hline 56 & & $1.4 \quad 154,835,151$ & $135,675,444$ & $53,218,993$ & $82,339,618$ & $94,564,453$ & 11.64 & 11.64 & 14.02 & 202.77 & 18.52 \\
\hline 57 & 1.4 & $42 \quad 154,365,417$ & $135,440,033$ & $51,467,525$ & $\begin{array}{l}82,785,714 \\
\end{array}$ & $95,738,141$ & 11.73 & 11.70 & 14.11 & 202.77 & 18.15 \\
\hline 58 & 1.4 & $44 \quad 154,006,200$ & $134,626,269$ & $50,782,641$ & $83,063,472$ & $96,541,596$ & 11.79 & 11.76 & 14.17 & 202.77 & 18.05 \\
\hline 59 & 1.4 & $46 \quad 153,778,993$ & $134,710,293$ & $50,099,768$ & $83,248,644$ & $97,114,026$ & 11.84 & 11.79 & 14.22 & 202.77 & 17.92 \\
\hline 60 & 1.4 & $\begin{array}{lll}483,362,897\end{array}$ & $133,681,893$ & $48,817,500$ & $83,534,819$ & $98,184,577$ & 11.92 & 11.84 & 14.30 & 202.77 & \\
\hline 61 & & 152,8 & & & 30 & 99432262 & 3 & 100 & 1439 & 20277 & \\
\hline
\end{tabular}




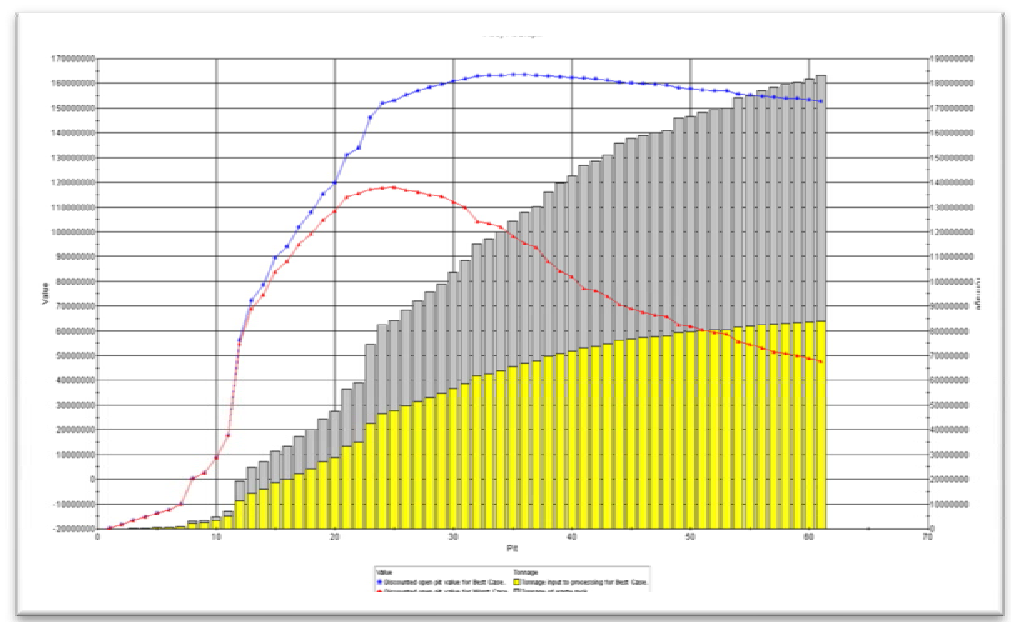

Figure 5 Pit by Pit Graph optimization per Scenario 2 - output Whittle Fx

Table 5 Mining dynamics per Scenario 2

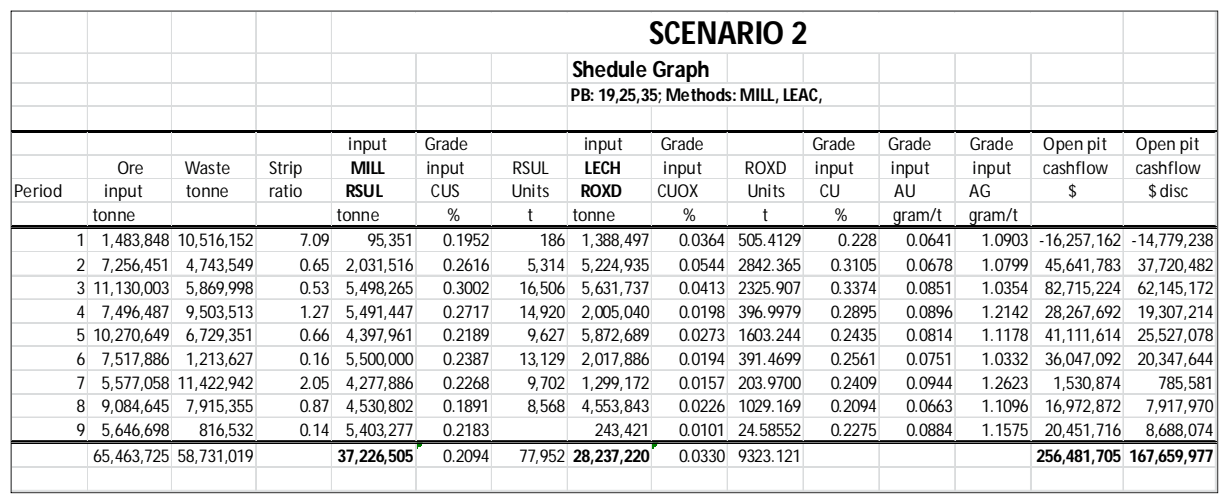

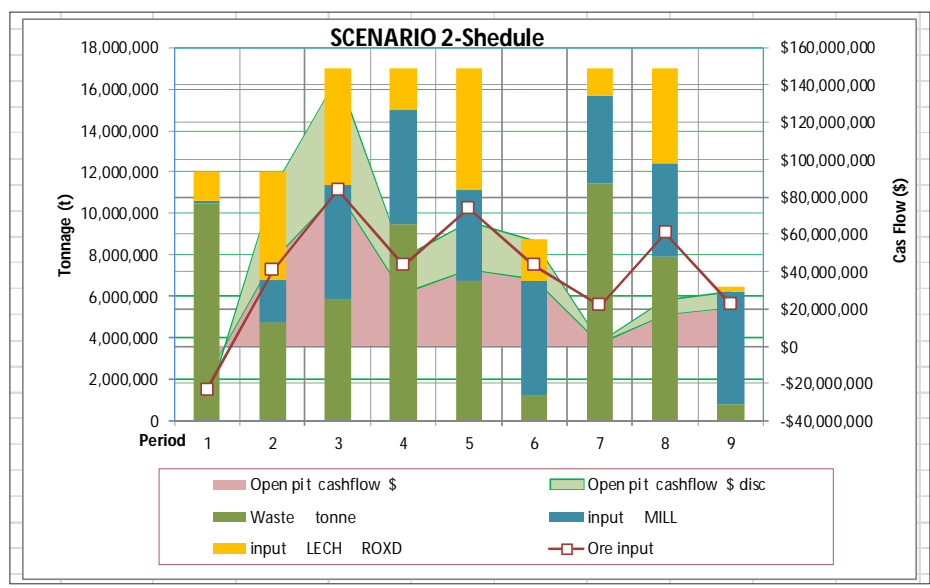

Figure 6 Graphical view of mining dynamics per Scenariio 2, two processing methods MILL and LEAC; selective ore mining at the open pit 
SCENARIO 3 Two Types of Processing

MILL (Flotation) and LEAC

(Heap leaching ) - Using Stock Pile

Table 6 Mining dynamics per Scenario 3
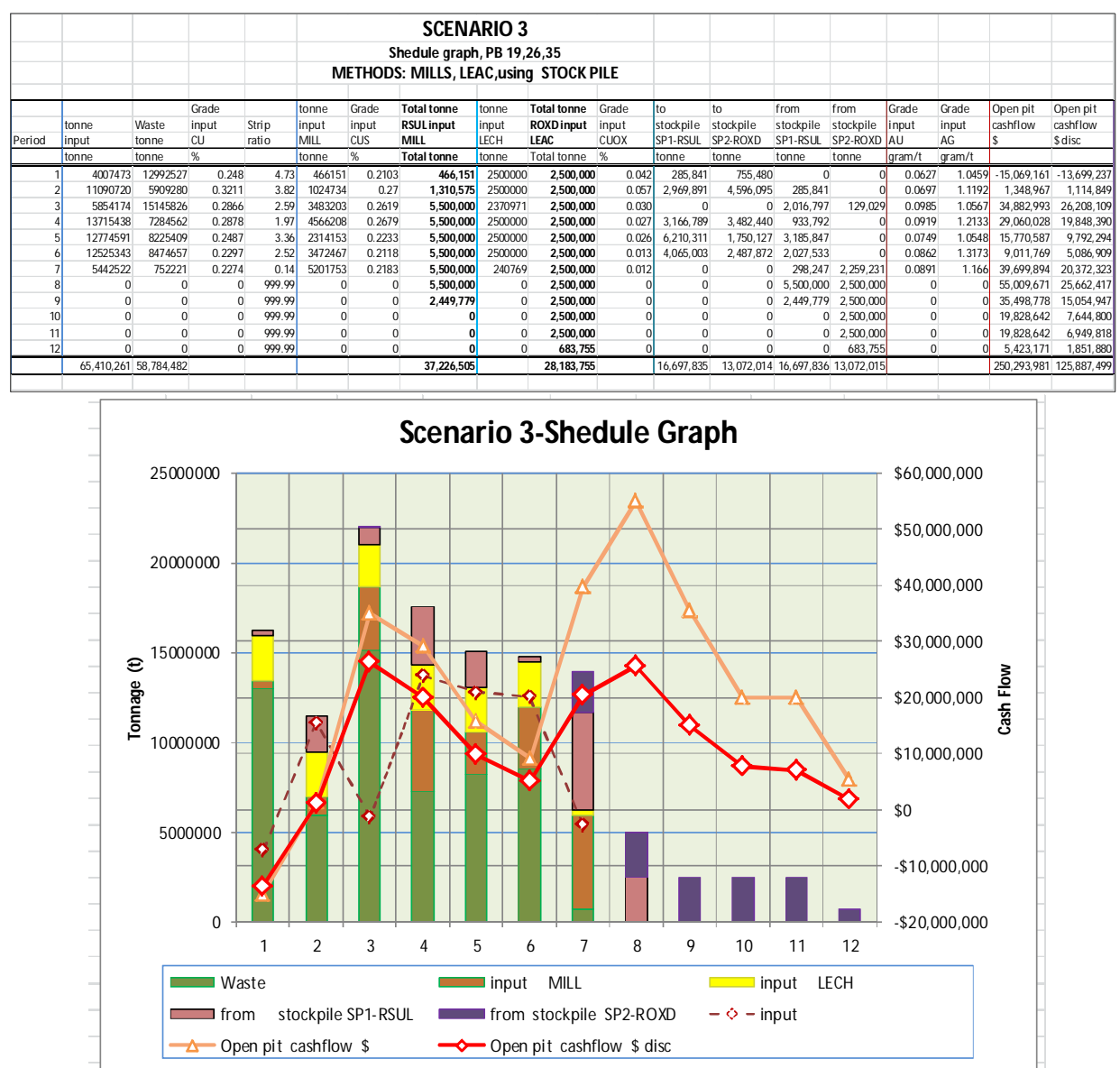

Figure 7 Graphical view of mining dynamics per Scenario 3 - twp processing methods MILL and LEA, selective ore mining at the open pit

\section{CONCLUSION}

The obtained possible open pits from the pit shells for Revenu Factor $1^{3}$ (i.e. the selling price of a tone of $\mathrm{Cu}$ cathode of

${ }^{3}$ Revenue Factor is a coefficient for multiplying the basic selling price of metal. In the case of this optimization the basic price is $\$ 5,000$, and RevFtr is in the range 0.3 do 1.5.
$5,000 \$$ ), are mutually different for about 8 million tons of ore in favor of combined method of processing, and the amounts of 
$\mathrm{Cu}$ in the ore for $16,502.44 \mathrm{t}$, while the had grade in the case of combination the processing method is higher for $3.27 \%$. Discounted cash flow is higher for even $61.94 \%$, as expressed in monetary units is 47,905,712\$.

These results of analysis, in addition to being a part of the input data related to leaching, solvent extraction and electrolysis - estimated on the basis of literature and experience in the world, and the degree of their accuracy is decreased, indicating in principle, to a significant improvement of economic results in the case of use the combined processing method. This suggests that it is needed to do more detailed tests (metallurgical test), which will increase the level of accuracy of the results to the level of relevance to business decision-making.

Table 7 Comparative presentation of the cash flow for three scenarios of processing

\begin{tabular}{|c|c|c|c|c|c|c|}
\hline \multirow{4}{*}{ Period } & \multicolumn{2}{|c|}{ Scenario 1} & \multicolumn{2}{|c|}{ Scenario 2} & \multicolumn{2}{|c|}{ Scenario 3} \\
\hline & Open pit & Open pit & Open pit & Open pit & Open pit & Open pit \\
\hline & cashflow & cashflow & cashflow & cashflow & cashflow & cashflow \\
\hline & $\$$ & \$disc & $\$$ & $\$$ disc & $\$$ & \$disc \\
\hline$\overline{1}$ & $-9,847,862$ & $-8,952,602$ & $-16,257,162$ & $-14,779,238$ & -15,069,161 & -13,699,237 \\
\hline 2 & $-3,387,689$ & $-2,799,743$ & $45,641,783$ & $37,720,482$ & $1,348,967$ & $1,114,849$ \\
\hline 3 & $6,867,290$ & $5,159,496$ & $82,715,224$ & $62,145,172$ & $34,882,993$ & $26,208,109$ \\
\hline 4 & $3,452,064$ & $2,357,806$ & $28,267,692$ & $19,307,214$ & $29,060,028$ & $19,848,390$ \\
\hline 5 & $15,477,799$ & $9,610,495$ & $41,111,614$ & $25,527,078$ & $15,770,587$ & $9,792,294$ \\
\hline 6 & $20,814,587$ & $11,749,292$ & $36,047,092$ & $20,347,644$ & $9,011,769$ & $5,086,909$ \\
\hline 7 & $28,194,533$ & $14,468,253$ & $1,530,874$ & 785,581 & $39,699,894$ & $20,372,323$ \\
\hline 8 & $23,064,615$ & $10,759,813$ & $16,972,872$ & $7,917,970$ & $55,009,671$ & $25,662,417$ \\
\hline 9 & $21,474,074$ & $9,107,104$ & $20,451,716$ & $8,688,074$ & $35,498,778$ & $15,054,947$ \\
\hline 10 & $27,995,708$ & $10,793,557$ & 0 & 0 & $19,828,642$ & $7,644,800$ \\
\hline 11 & $28,542,461$ & $10,003,959$ & 0 & 0 & $19,828,642$ & $6,949,818$ \\
\hline 12 & $17,194,580$ & $5,724,357$ & 0 & 0 & $5,423,171$ & $1,851,880$ \\
\hline & $1779,842,160$ & $77,981,787$ & $256,481,705$ & $167,659,977$ & $250,293,981$ & $125,887,499$ \\
\hline
\end{tabular}

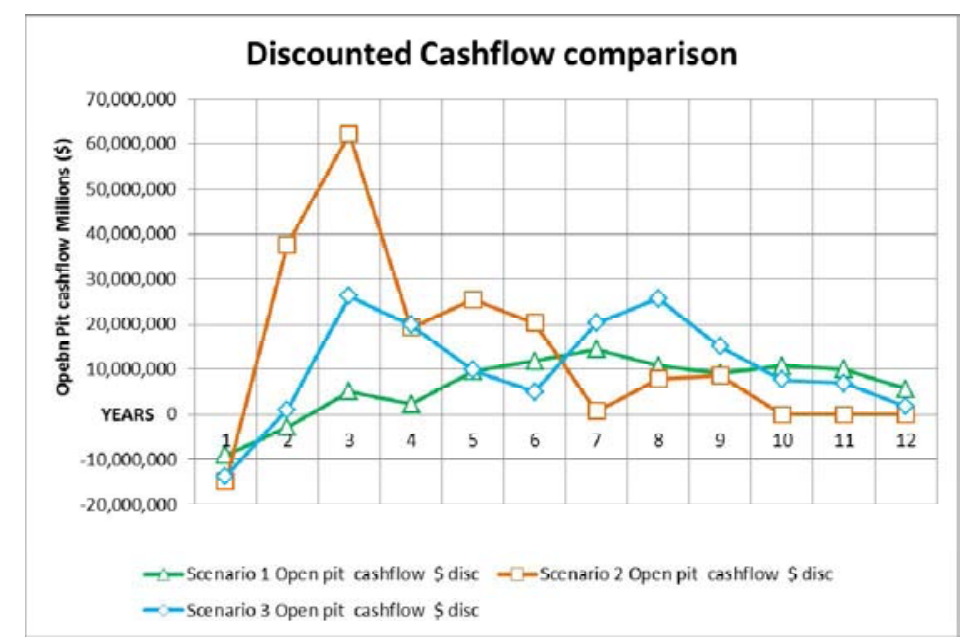

Figure 8 Graph of comparative presentation of cash flow for all three scenarios of processing 
Difference in the discounted cash flow (total and incremental per year) between the analyzed Scenarios 1 and 2 is significant, while between 2 and 3 is not too large, even in favor of scenario without the use of stock piles, but it may be the result of insufficient knowledge of the actual techno - economic parameters of leaching process.

In this analysis mostly literature data on leaching have been used [1,7], and partly based data on the assessed values of other's experiences and conclusions and comparisons with pyrometallurgical method of processing, where there is sufficient data. It is especially important for heap leaching to determine: recovery of basic and precious metals, as well as leaching time, also the costs of leaching pad preparation, consumption of acid, consumption of foil for substrate preparation, installation of distribution for acid (cyanide) and other normative materials as well as the costs of obtaining metals from leaching solutions in the metallurgical process of treatment. All of these costs should be kept to a ton of ore, ore a tone of the final product in the way defined by software Whittle and in the analysis of acceptance the input costs.

The authors of the paper work did not have the ambition to deal in this analysis with the technology of leaching (detailed technique and chemistry of the leaching process. They are of the other specialties, but to compare the economic effects of these cases of the applied methods of extraction the primary and associated precious metals, and based on that to make the certain conclusions presented in the paper.

The previous opinion of some experts as well as the inhabitants in the localities of ore deposits - Cerovo-Kraku Bugaresku, Ujova River and other current and potential localities, at which the deposits are located with similar characteristics, is that the leaching process is highly hazardous to the environment. Such opinion is denied in the world, inter alia, and because the total world production of copper, about $20 \%$, is obtained by leaching. The most developed countries in the world do that because they take much more account of environmental protection than we do, and whose regulations in this area are far more stringent than ours (the United States, Chile, Canada, South Africa and others).

The purpose of this analysis is to highlight the potential alternative method which can increase the profit from the exploitation of deposits containing high contents of oxide minerals in the ore, which adversely affect the metal recovery in flotation method of enrichment. The analysis of this type, even it is the case of doubt whether even to exploit such deposits, i.e. whether the economics of exploitation is satisfactory, as there are conflicting opinions in the local professional community, can provide the adequate data for relevant qualified evaluation and decision.

It is important to note that it is the trend of leaching technology is also leaching of sulphide concentrates.

\section{REFERENCES}

[1] J. Peacey ${ }^{1}$, G. Xian-Jian ${ }^{1}$, E. Robles ${ }^{2}$ : ,Copper Hydrometallurgy-Current Status, Preliminary Economics, Future Direction and Positioning Versus Smelting, J. Peacey ${ }^{1}$, GUO Xian-Jian ${ }^{1}$, E. Robles ${ }^{2,1}$ Hatch Associates Ltd., 2800 Speakman Drive, Mississauaga, Ontario L5K 2R7, Canada; ${ }^{2}$ Hatch IngenierosyConsultores Ltda., San Sebastian 283, Piso 9, Los Condes, Santiago 6760226, Chile;

[2] J. F. Lupo: Design and Operation of Heap Leach Pads, By: John F. Lupo, Ph.D. Golder Asociates;

[3] C. Avendaño Varas: Review on Heap Leaching of Copper Ores, Carlos Avendaño Varas, Chemical Engenieer, Sociedad Terral S.A;

[4] R. Denis, M. Marcotte: 1,7 Million Square Meters PVC Heap Leach Pad Case History,Robert Denis, Solmax 
International Inc., Varennes, Qc., Canada, Michel Marcotte, Genivar, Montreal, Qc., Canada, Draft paper submitted for publication GeoAfrica 2009;

[5] M. E. Orman, D. Romo, R. Tremayne: A Case Study of the Ocampo Phase 1 Heap Leach Expansion or Changing a Flat Pad to a Valley Fill, By: Marc E. Orman, David Romo, Russell Tremayne;

[6] Whittle Strategic Mine Planning, Gemcom Whittle ${ }^{\mathrm{TM}}$ Copyright (C) 2012 Gemcom Software International Inc.;
[7] G. Hovanec, Review of the Basic Economic Aspects of Copper Production Using the Method Acid Leaching, Mining Institute, Belgrade; (in Serbian)

[8] Z. Vaduvesković, M. Bugarin, D. Kržanović, Stripping Delaz Analysis in Relation to Designed Long-Term Plan of Excavation at the Open Pit Veliki Krivelj, Mining and Metallurgy Engineering Bor, 2/2013, pp.33-42.

[9] J. Vukašinović, J. Đorđević Boljanović, Mining Industry in the Knowledge Economy, Mining and Metallurgy Engineering Bor, 2/2013, pp. 117-126. 


\begin{tabular}{ll}
\hline \hline INSTITUT ZA RUDARSTVO I METALURGIJU BOR & ISSN: 2334-8836 \\
& UDK: 622 \\
\hline \hline
\end{tabular}

\section{ANALIZA MOGUĆNOSTI POBOLJŠANJA EKONOMSKIH POKAZATELJA EKSPLOATACIJE LEŽIŠTA CEMENTACIJA KRAKU BUGARESKU - RUDNO POLJE CEROVO***}

Izvod

Cementacija Kraku Bugaresku je kompleks rudnih tela u jugoistočnom delu ležišta Cerovo. Sadrži znatan deo rude sa povećanim sadržajem oksida u odnosu na ukupan bakar u rudi, i sa postojećom tehnologijom prerade u dosadašnjem periodu postignutisu skromni rezultati u iskorišćenju metala.

Ovaj članak kroz analizu razmatra moguću kombinaciju metoda prerade klasičnom flotacijskom preradom sa pirometalurškom preradom i luženja na gomili sa hidrometalurškom ekstrakcijom metala postupkom SX-EW, sa aspekta ekonomske isplativosti takvog postupka. U članku je izvršeno najpre upoređenje rezultata optimizacije mogućih kopova na rudnom ležištu (Whittle Fx), u jednom i drugom slučaju za iste ulazne tehnoekonomske podatke. Dobijeni mogući kopovi iz procesa optimizacije (pit shells), za Revenu Factor 1 ( $t j$. prodajnu cenu tone Cu katode od 5000 \$), međusobno se razlikuju za oko 8 miliona tona rude u korist kombinovane metode prerade, a količine Cu u rudi za 16.502,44 t, dok je srednji sadržaj (had grade) u slučaju kombinacije metoda prerade veći za 3,27\%. Diskontovani novčani tok (Cash Flow) je veći za čak 61,94\%, što izraženo u novčanim jedinicama iznosi 47.905 .712 \$.

Keywords: luženje na gomili, SX-EV, optimizacija kopova, diskontovani novčani tok.

\section{UVOD}

Rudno polje Kraku Bugaresku (KB) Cementacija je deo kompleksa rudnih ležišta na lokalitetu Cerovo Mali Krivelj, koje se razlikuje od ostatka ležišta prema načinu nastanka i vrsti orudnjenja. To je cementaciona zona sekundarnog obogaćenja, i jedan deo orudnjenja spada u oksidne mineralizacije (oko 40\% od ukupnih geoloških rezervi). Sastoji se od rudnih tela Cementacija 1, 2, 3 i 4 od kojih se prema sadržaju oksidne

rude u odnosu na ukupne rezerve, izdvajaju cementacija 3 i 4. Prema sadržaju bakra, ovaj kompleks spada u siromašna ležišta čija je ekonomika eksploatacije vrlo osetljiva na pojedine parametre kao što su iskorišćenje metala u procesu obogaćenja, troškove eksploatacije u tehnološkom lancu od otkopavanja do metalurške prerade, pa čak i redosleda otkopavanja rudnih tela (Push backs) unutar cementacione zone.

\footnotetext{
* Institut za rudarstvo i metalurgiju Bor

*** Univerzitet u Beogradu,Tehnički fakultet Bor

**** Članak je u sklopu projekata tehnološkog razvoja TR 33038 "Usavršavanje tehnologija eksploatacije $i$ prerade rude bakra sa monitoringom životne i radne sredine u RTB Bor Grupa" $i$ TR 34004 "Nova proizvodna linija za dobijanje bakra solventnom ekstrakcijom rudničkih voda", koji su finansirani od strane Ministarstva prosvete, nauke i tehnološkog razvoja.
} 
Na sl. 1. prikazana je analiza "Grade tonnage“" za različite granične sadržaje (Cutoff), što predstavlja karakteristiku ležišta, odakle se vidi odnos količina RSULF i ROXD, tj. količine jedne i druge vrste rude u ležištu.
Najzastupljeniji minerali bakra $\mathrm{u}$ gornjem delu ležišta, oksidacionoj zoni su kuprit, malahit i azurit, dok su u zoni sekundarnog sulfidnog obogaćenja najzastupljeniji kovelin i halkozin.

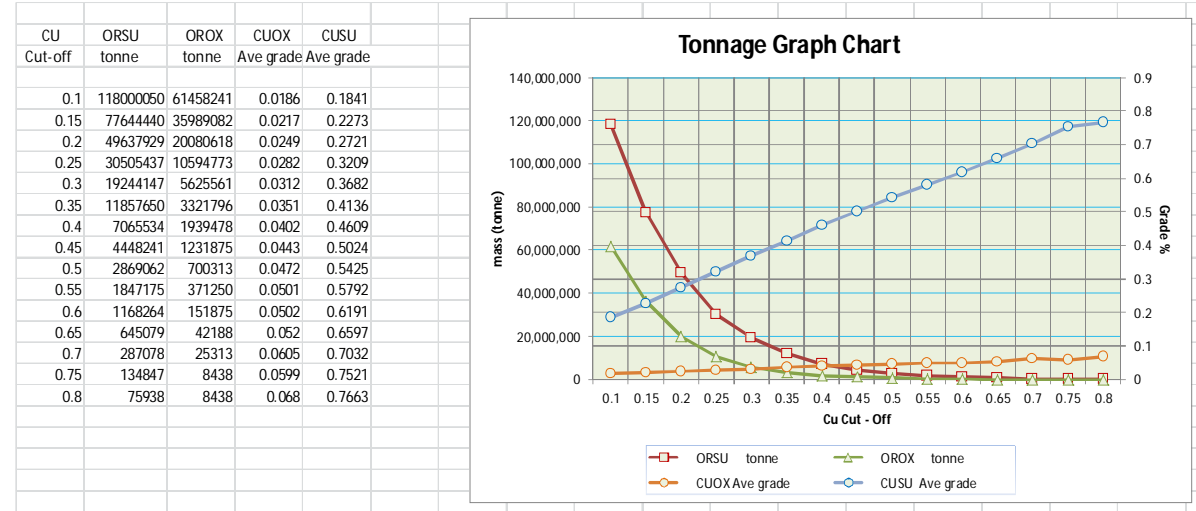

SI. 1. “Grade tonnage” analiza za ležište rude bakra KB Cementacija za različite granične sadržaje - tabela i grafik

Dosadašnji način rada primenjen na eksploataciji ležišta Cementacija 1 , koji se sastojao u flotacijskoj preradi celokupne količine rude iznad graničnog sadržaja, bez razdvajanja oksidnih partija rude od sulfidnih, rezultirao je niskim iskorišćenjem bakra u flotaciji koje se kretalo u intervalu između 50 i $70 \%{ }^{1}$. To je svakako negativno uticalo i na ostvarene ekonomske rezultate.
Upravo zbog navedenih činjenica vrlo je značajno razmatranje i analiza mogućnosti povećanja NPV-a, odnosno Cashflow-a u eksploataciji ovog kompleksa rudnih tela.

$\mathrm{Na}$ sadašnjem nivou tehnološkog razvoja eksploatacije $\mathrm{i}$ iskorišćenja metala iz oksidnih i sulfidnih ruda, u poslednje vreme se značaj pridaje luženju $i$ solventnoj ekstrakciji lužnih rastvora iz oksidnih ruda, pa čak i iz sulfidnih ruda (ili koncentrata).

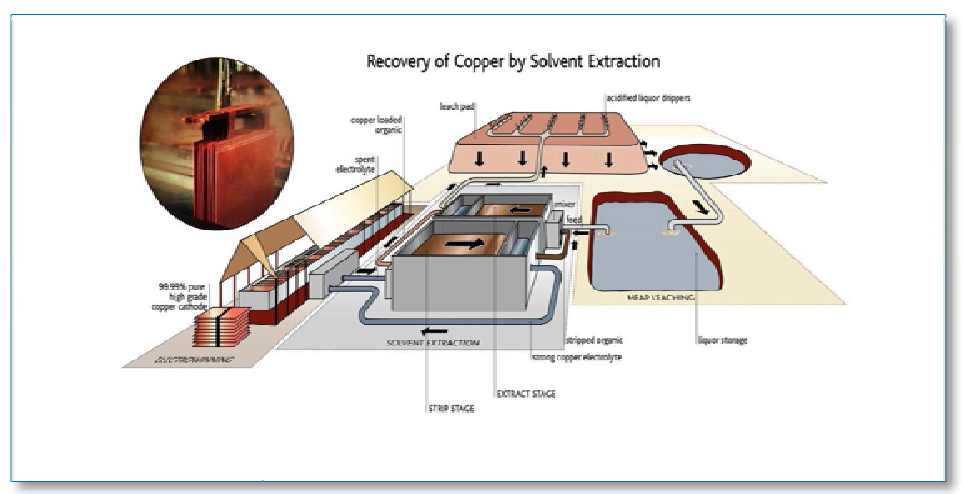

Sl. 2. Šematski Process Flow Diagram - Heap leach, Solvent Extraction and Electro Wining

${ }^{1}$ U zvaničnim dokumentima (Godišnji tehnički izveštaji proizvodnje RBB, 1993. -2000. godine) proizvodni rezultati nisu verodostojno prikazani 


\section{ANALIZA U SOFTVERU ZA STRATEŠKO PLANIRANJE WHITTLE FX}

Ulazni tehnoekonomski podaci za analizu vršenu u softveru za strateško planiranje Whittle Fx, za scenario 1. i 2., tj. flotiranje sulfidne i oksidne rude zajedno, bez selek- tivnog otkopavanja i selektivno otkopavanje sa dodatnom metodom metode obogaćivanja - luženjem na gomili rude sa preko 10\% oksida, su sledeći:

Tabela 1. Ulazni tehno-ekonomski parametri eksploatacije za proces optimizacije (input)

\begin{tabular}{|lcr|}
\hline \multicolumn{1}{|c}{ Parametar } & Jedinica & \multicolumn{1}{c|}{ Vrednosti } \\
\hline Kapacitet otkopavanja - iskopine & t/god & 12Mt od 3.godine 17 Mt \\
$\begin{array}{l}\text { Kapacitet flotacijske prerade - Sulfidna } \\
\text { ruda sa max. 10\% oksidne }\end{array}$ & t/god & 2,5Mt od 3. Godine 5,5 Mt \\
$\begin{array}{l}\text { Kapacitet luženja na gomili - Oksidna } \\
\text { ruda sa preko 10\% sadržajem oksida }\end{array}$ & t/god & $2.5 \mathrm{Mt}$ \\
Cena bakra & $\$ /$ tkatode & $5,000.00$ \\
Cena zlata & $\$ / \mathrm{kg}$ & $40,000.00$ \\
Cena srebra & $\$ / \mathrm{kg}$ & 500.00 \\
Troškovi otkopavanja & $\$ / \mathrm{t}$ & $2,3$. \\
Troškovi flotacijske prerade & $\$ / \mathrm{t}$ & 4,00 \\
Troškovi prerade luženjem na gomili & $\$ / \mathrm{t}$ rude & 1.00 \\
Troškovi metalurške prerade bakra & $\$ / \mathrm{t} \mathrm{katode}$ & 450.00 \\
Troškovi metalurške prerade zlata & $\$ / \mathrm{kg}$ & 150.00 \\
Troškovi metalurške prerade srebra & $\$ / \mathrm{kg}$ & 15.00 \\
Troškovi hidrometalurške prerade & $\$ / \mathrm{t}$ katode & 100.0 \\
(SXEW) & $\$$ & $20,000,000$ \\
Inicijalni kapitalni troškovi luženja i & $\%$ & 0,788 \\
SXEW & $\%$ & 0,50 \\
Ukupno iskorišćenje bakra (flot i metal) & $\%$ & 0,40 \\
Ukupno iskorišćenje zlata (flot i metal) & $\%$ & 0,54 \\
Iskorišćenje srebra (flot i metal) & $\%$ & 10.0 \\
\hline $\begin{array}{l}\text { Iskorišćnje bakra iz oksidne rude sa } \\
\text { preko 10\% sadržajem oksida }\end{array}$ & $\%$ & \\
Diskontna stopa & $\%$ & \\
\hline
\end{tabular}


Analiza $^{2}$ je vršena za 3 scenarija, i to:

1. Scenario 1 - metoda prerade označena sa „MILL“ tj. flotiranje ROXD i RSULF, odnosno dva tipa rude;

2. Scenario 2 - metoda „MILL“ za rudu sa $>10 \%$ oksida, i metoda „LEAC“ za rudu sa sadržajem $>10 \%$ oksida, pri čemu nije ograničen kapacitet luženja;

3. Scenario 3 - isti kao scenario 2, ali sa ograničenjem kapaciteta luženja na $2.500 .000 \mathrm{t}$, i sa korišćenjem dve vrste skladišta (Stock Piles) za rudu do $10 \%$ oksida i rudu $>10 \%$ oksida (SP1 i SP2). Skladišta su korišćena kao "buffer" za dopunu projektovanog kapaciteta kako u flotaciji, tako i na luženju.

U daljoj analizi za SCENARIO 1 i 2 su tabelarno prikazani rezultati optimizacije u tabelama tipa Pit By Pit Garph, tj. kopovi iz optimizacije sa sračunatim novčanim tokom i diskontovanim novčanim tokom za svaki kop iz seta ugnježdenih kopova. Ekonomski pokazatelji su sračunati za tri moguća slučaja - Best Case, Worst Case i Specific Case, tj za radne uglove kosina na kopu jednakim $0^{\circ}$, maximalni radni ugao i specifičan (izabrani) kop. Merodavan za ocenu i izbor optimalnog kopa po kriterijumu optimalnog profita je diskontovani novčani tok (cash flow) za maksimalni radni ugao. To znači da se izabrani kop (Final pit) otkopava po fazama (Push backs).

Za sva tri slučaja je projektovana i sračunata dinamika otkopavanja za vek eksploatacije izabranog kopa po navedenom kriterijumu, sa odgovarajućim grafičkim prikazom. Takođe su u tabelama prikazane $\mathrm{i}$ obračunate količine po vrstama rude (kao Rock Type), sa manjim i većim sadržajem oksida, odnosno ostvarenim kapacitetima za metodu "MILL" i metodu"LEAC", u scenariju 3. - sa dodatnim obračunatim količinama rude koje idu na skladište i koje sa skladišta idu u procese.

\footnotetext{
${ }^{2}$ Pored napred navedenih ulaznih podataka, $u$ softver Whittle se unosi i blok model ležišta, tzv. mod fajl. U kreiranju navedenog u osnovnom softveru, u ovom slučaju Gemcom, koristi se i topografija terena, odnosno stanje rudarskih radova na rudniku. U slučaju ove analize, stanje terena je 10.08.2001., $t j$. stanje pre ponovnog aktiviranja kopa, upravo zbog toga što analiza nije rađena u sklopu Studije ili projekta, nego je urađena sa svrhom da ukaže na mogućnosti povećanja ekonomskih efekata proizvodnje i pokrene značajnija istraživanja u pravcu extrakcije $\mathrm{Cu}$ i pratećih plemenitih metala hidrometalurškim postupkom.
} 


\section{SCENARIO 1. Jedan tip prerade MILL}

(flotiranje) sulfidne i oksidne rude zajedno

Tabela 2. Tabelarni prikaz rezultata optimizacije po Scenariju 1, sa obračunatim novčanog toka

\begin{tabular}{|c|c|c|c|c|c|c|c|c|c|}
\hline & & & & PIT BY & PIT GR & $\mathrm{APH}$ & SCENA & 101 & \\
\hline & & & & & & & & & \\
\hline & Revenue & & & & & & & & \\
\hline & factor & Open pit & Open pit & Open pit & & & Mine & Mine & Mine \\
\hline & for & cashflow & cashflow & cashflow & tonne & Waste & life & life & life \\
\hline Final & final & best & specified & worst & input & best & years & years & years \\
\hline pit & pit & $\$$ disc & $\$$ disc & $\$$ disc & best & tonne & best & specified & worst \\
\hline 1 & 0.32 & $1,257,649$ & $1,257,649$ & $1,257,649$ & 64,520 & 9,407 & 0.03 & 0.03 & 0.03 \\
\hline 2 & 0.34 & $2,340,019$ & $2,340,019$ & $2,340,019$ & 127,897 & 9,971 & 0.05 & 0.05 & 0.05 \\
\hline 3 & 0.36 & $3,265,188$ & $3,265,188$ & $3,265,188$ & 188,088 & 10,150 & 0.08 & 0.08 & 0.08 \\
\hline 4 & $0.3 \varepsilon$ & $4,415,908$ & $4,415,908$ & $4,415,908$ & 272,142 & 14,544 & 0.11 & 0.11 & 0.11 \\
\hline 5 & 0.4 & $5,121,194$ & $5,121,194$ & $5,121,194$ & 326,594 & 28,340 & 0.13 & 0.13 & 0.13 \\
\hline 6 & 0.42 & $6,782,948$ & $6,782,948$ & $6,782,948$ & 475,371 & 39,226 & 0.19 & 0.19 & 0.19 \\
\hline 7 & 0.44 & $8,622,922$ & $8,622,922$ & $8,622,922$ & 654,558 & 64,086 & 0.26 & 0.26 & 0.26 \\
\hline 8 & 0.46 & $5 \quad 10,525,070$ & $10,525,070$ & $10,525,070$ & 868,580 & 85,685 & 0.35 & 0.35 & 0.35 \\
\hline 9 & $0.4 \varepsilon$ & $\begin{array}{ll}3 & 13,053,414\end{array}$ & $13,053,414$ & $13,053,414$ & $1,188,709$ & 111,857 & 0.48 & 0.48 & 0.48 \\
\hline 10 & 0.5 & $\begin{array}{ll}5 & 15,071,636\end{array}$ & $15,071,636$ & $15,071,636$ & $1,480,565$ & 120,560 & 0.59 & 0.59 & 0.59 \\
\hline 11 & 0.52 & $\begin{array}{ll}2 & 15,737,824\end{array}$ & $15,737,824$ & $15,737,824$ & $1,589,257$ & 128,947 & 0.64 & 0.64 & 0.64 \\
\hline 12 & 0.54 & $\begin{array}{l}4 \\
18,383,286\end{array}$ & $18,383,286$ & $18,383,286$ & $2,040,985$ & 229,016 & 0.82 & 0.82 & 0.82 \\
\hline 13 & 0.56 & $\begin{array}{ll}5 & 20,388,697\end{array}$ & $20,388,697$ & $20,388,697$ & $2,429,329$ & 299,806 & 0.97 & 0.97 & 0.97 \\
\hline 14 & 0.58 & $\begin{array}{ll}3 & 21,534,215\end{array}$ & $21,532,415$ & $21,532,415$ & $2,663,808$ & 335,688 & 1.07 & 1.07 & 1.07 \\
\hline 15 & 0.6 & $\begin{array}{ll}5 & 48,788,934\end{array}$ & $47,538,914$ & $47,538,914$ & $7,875,043$ & $5,582,314$ & 2.52 & 2.52 & 2.52 \\
\hline 16 & 0.62 & $255,146,867$ & $53,508,008$ & $53,508,008$ & $9,599,654$ & $6,485,167$ & 2.84 & 2.84 & 2.84 \\
\hline 17 & 0.6 & $\begin{array}{l}4 \quad 63,570,562 \\
\end{array}$ & $60,902,078$ & $60,902,078$ & $11,991,784$ & $7,986,686$ & 3.27 & 3.27 & 3.27 \\
\hline 18 & 0.66 & $6 \quad 67,546,940$ & $64,308,942$ & $64,308,942$ & $13,194,047$ & $8,727,104$ & 3.49 & 3.49 & 3.49 \\
\hline 19 & $0.6 \varepsilon$ & $\begin{array}{l}3 \\
76,251,473\end{array}$ & $71,761,565$ & $71,761,565$ & $16,394,020$ & $10,505,786$ & 4.07 & 4.07 & 4.07 \\
\hline 20 & 0.7 & $\begin{array}{l}7 \\
79,816,489\end{array}$ & $74,837,962$ & $74,837,962$ & $17,911,544$ & $11,034,033$ & 4.35 & 4.35 & 4.35 \\
\hline 21 & 0.72 & $284,775,931$ & $78,120,000$ & $78,120,000$ & $20,275,932$ & $12,509,270$ & 4.78 & 4.78 & 4.78 \\
\hline 22 & 0.74 & $4 \quad 87,297,954$ & $79,729,295$ & $79,729,295$ & $21,721,280$ & $13,173,614$ & 5.04 & 5.04 & 5.04 \\
\hline 23 & 0.76 & $6 \quad 99,408,000$ & $82,884,123$ & $82,884,123$ & $28,647,492$ & $19,642,382$ & 6.30 & 6.55 & 6.55 \\
\hline 24 & $0.7 \varepsilon$ & $3102,648,142$ & $83,151,343$ & $83,151,343$ & $31,079,978$ & $21,409,083$ & 6.74 & 7.05 & 7.05 \\
\hline 25 & $0 . \varepsilon$ & B 105,911,193 & $82,932,523$ & $82,932,523$ & $33,864,262$ & $24,482,200$ & 7.25 & 7.62 & 7.62 \\
\hline 26 & 0.82 & $107,796,516$ & $83,166,000$ & $83,166,000$ & $36,026,740$ & $25,479,248$ & 7.64 & 8.02 & 8.02 \\
\hline 27 & 0.84 & $4 \quad 109,864,961$ & $82,857,682$ & $82,857,682$ & $38,690,541$ & $27,906,217$ & 8.13 & 8.52 & 8.52 \\
\hline 28 & 0.86 & $5 \quad 112,055,441$ & $81,155,078$ & $81,155,078$ & $41,754,095$ & $31,007,667$ & 8.68 & 9.10 & 9.10 \\
\hline 29 & 0.88 & $8113,121,606$ & $80,039,265$ & $80,039,265$ & $43,695,298$ & $33,065,173$ & 9.04 & 9.46 & 9.46 \\
\hline 30 & 0.9 & $9115,083,888$ & $75,541,273$ & $75,541,273$ & $48,341,430$ & $37,235,782$ & 9.88 & 10.32 & 10.32 \\
\hline 31 & 0.92 & $2115,955,763$ & $71,519,775$ & $71,519,775$ & $50,942,253$ & $40,014,353$ & 10.35 & 10.89 & 10.89 \\
\hline 32 & 0.94 & $416,329,206$ & $69,437,935$ & $69,437,935$ & $52,691,741$ & $42,144,430$ & 10.67 & 11.24 & 11.24 \\
\hline 33 & 0.96 & $5116,577,596$ & $67,166,852$ & $67,166,852$ & $54,558,738$ & $44,257,231$ & 11.01 & 11.62 & 11.62 \\
\hline 34 & 0.98 & $3116,812,522$ & $63,546,156$ & $63,546,156$ & $56,940,722$ & $47,520,092$ & 11.44 & 12.10 & 12.10 \\
\hline 35 & & $116,822,322$ & $62,763,271$ & $62,763,271$ & $57,462,570$ & $48,143,878$ & 11.54 & 12.20 & 12.20 \\
\hline 36 & 1.02 & $2116,733,132$ & $60,247,593$ & $60,247,593$ & $59,523,326$ & $50,336,326$ & 11.91 & 12.60 & 12.60 \\
\hline 37 & 1.04 & $4116,570,305$ & $57,088,898$ & $57,088,898$ & $61,004,701$ & $52,645,714$ & 12.18 & 12.91 & 12.91 \\
\hline 38 & 1.06 & $5 \quad 116,246,697$ & $53,548,340$ & $53,548,340$ & $62,679,665$ & $55,723,640$ & 12.49 & 13.27 & 13.27 \\
\hline 39 & 1.08 & $3116,104,201$ & $52,612,974$ & $52,612,974$ & $63,285,683$ & $56,807,448$ & 12.60 & 13.38 & 13.38 \\
\hline 40 & 1.1 & $115,890,094$ & $51,230,325$ & $51,230,325$ & $63,973,933$ & $57,909,775$ & 12.72 & 13.51 & 13.51 \\
\hline 41 & 1.12 & $2114,776,583$ & $41,519,881$ & $41,519,881$ & $67,492,199$ & $62,846,779$ & 13.36 & 14.34 & 14.34 \\
\hline 42 & 1.14 & $114,282,584$ & $37,924,212$ & $37,924,212$ & $68,822,070$ & $65,024,645$ & 13.60 & 14.65 & 14.65 \\
\hline 43 & 1.16 & $5114,198,024$ & $37,513,600$ & $37,513,600$ & $69,049,326$ & $65,188,415$ & 13.65 & 14.69 & 14.69 \\
\hline 44 & 1.18 & $8113,547,212$ & $35,394,348$ & $35,394,348$ & $70,505,451$ & $68,088,287$ & 13.91 & 14.96 & 14.96 \\
\hline 45 & 1.2 & $2113,180,094$ & $34,216,439$ & $34,216,439$ & $71,313,473$ & $69,376,637$ & 14.06 & 15.11 & 15.11 \\
\hline 46 & 1.22 & $112,692,740$ & $31,159,282$ & $31,159,282$ & $72,264,584$ & $71,233,186$ & 14.23 & 15.34 & 15.34 \\
\hline 47 & 1.24 & $4112,393,820$ & $29,204,421$ & $29,204,421$ & $72,820,099$ & $72,285,894$ & 14.33 & 15.48 & 15.48 \\
\hline 48 & 1.26 & $5 \quad 110,665,910$ & $18,407,558$ & $18,407,558$ & $75,656,596$ & $79,276,775$ & 14.86 & 16.25 & 16.25 \\
\hline 49 & 1.28 & $3109,992,003$ & $16,490,497$ & $16,490,497$ & $76,759,211$ & $81,937,428$ & 15.15 & 16.46 & 16.46 \\
\hline 50 & 1.3 & $3109,028,005$ & $11,329,090$ & $11,329,090$ & $78,333,172$ & $85,123,865$ & 15.43 & 16.80 & 16.80 \\
\hline 51 & 1.32 & $2108,936,513$ & $10,951,659$ & $10,951,659$ & $78,476,259$ & $85,430,456$ & 15.46 & 16.83 & 16.83 \\
\hline 52 & 1.34 & $4108,604,954$ & $9,631,895$ & $9,631,895$ & $78,947,606$ & $86,580,421$ & 15.54 & 16.93 & 16.93 \\
\hline 53 & 1.36 & $5 \quad 108,528,079$ & $9,319,586$ & $9,319,586$ & $79,090,693$ & $86,744,802$ & 15.57 & 16.96 & 16.96 \\
\hline 54 & 1.38 & $\begin{array}{ll}3 & 107,646,094\end{array}$ & $6,399,243$ & $6,399,243$ & $80,168,057$ & $89,781,653$ & 15.77 & 17.17 & 17.17 \\
\hline 55 & 1.4 & $106,959,546$ & $4,034,446$ & $4,034,446$ & $81,102,333$ & $92,015,091$ & 15.94 & 17.35 & 17.35 \\
\hline 56 & 1.42 & $2106,704,144$ & $3,213,701$ & $3,213,701$ & $81,439,009$ & $92,833,624$ & 16.00 & 17.41 & 17.41 \\
\hline 57 & 1.44 & $4106,461,667$ & $2,659,448$ & $2,659,448$ & $81,716,767$ & $93,627,441$ & 16.06 & 17.47 & 17.47 \\
\hline 58 & 1.46 & $5 \quad 106,136,964$ & $1,975,632$ & $1,975,632$ & $82,087,111$ & $94,621,529$ & 16.14 & 17.53 & 17.53 \\
\hline 59 & $1.4 \varepsilon$ & B $106,087,512$ & $1,742,133$ & $1,742,133$ & $82,154,446$ & $94,741,304$ & 16.15 & 17.55 & 17.55 \\
\hline 60 & 1.5 & $5105,680,501$ & 702,770 & 702,770 & $82,533,207$ & $96,158,579$ & 16.25 & 17.62 & 17.62 \\
\hline
\end{tabular}




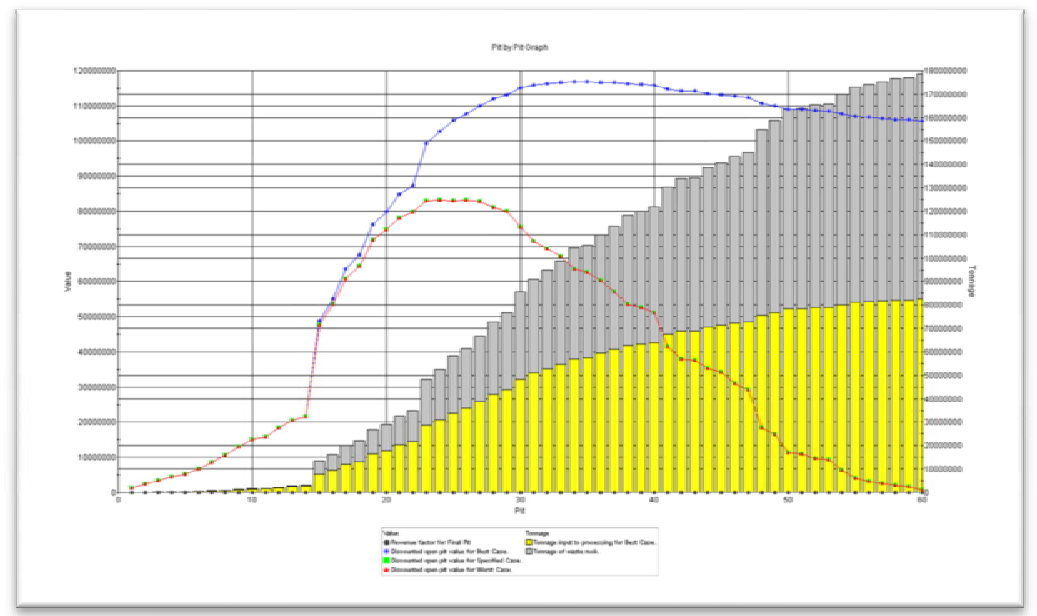

Sl. 3. Pit by Pit graph - Grafik optimizacije po Scenariju 1

Tabela 3. Dinamika otkopavanja po Scenariju 1

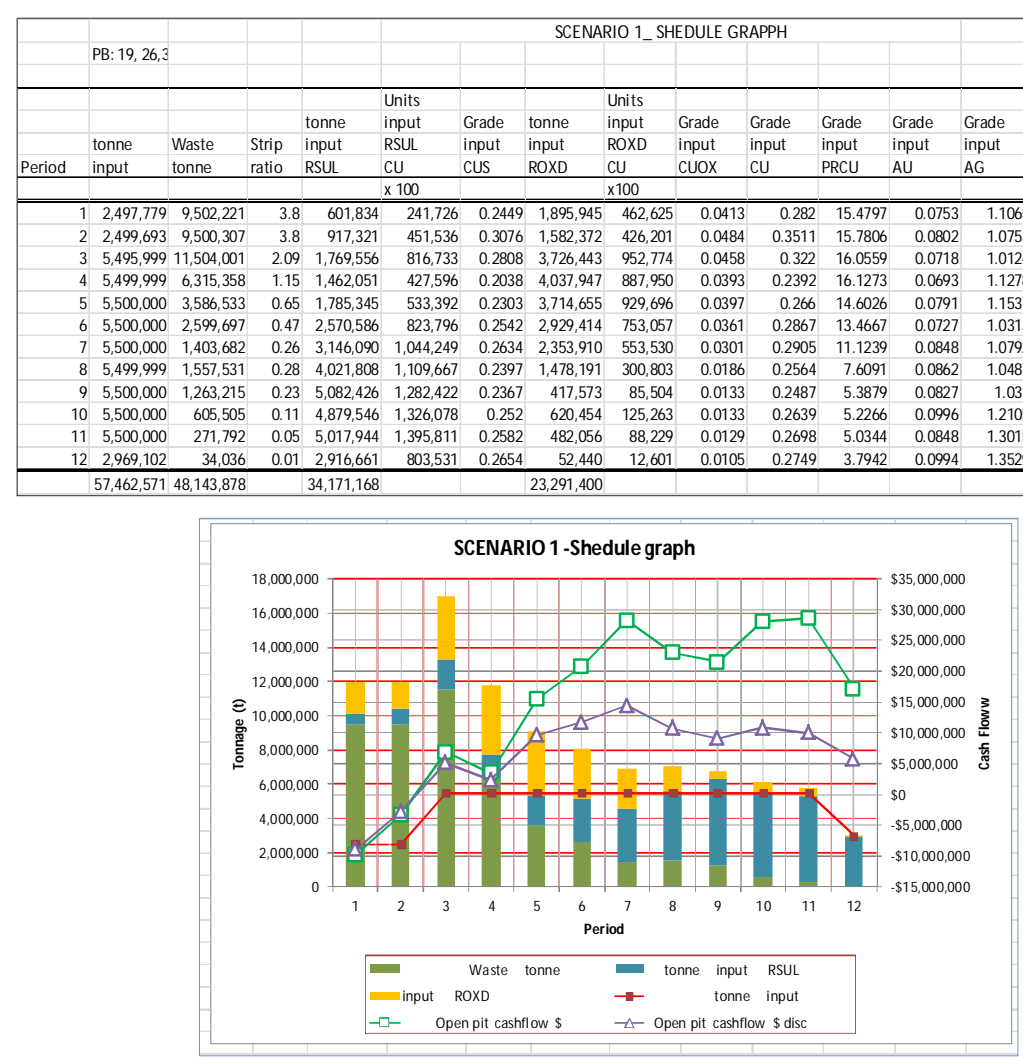

S1. 4. Grafički prikaz DINAMIKE otkopavanja po Scenariju 1, sa jednom metodom prerade - MILL; ukupne količine rude bez selektivnog otkopavanja idu u flotacijsku preradu i koncentrat na pirometalurški postupak 
SCENARIO 2. Dva tipa prerade MILL

(flotiranje) i HEAP LEACHING

(luženje na gomili)

Tabela 4. Tabelarni prikaz rezultata optimizacije po Scenariju 2, sa obračunatim CashFlow

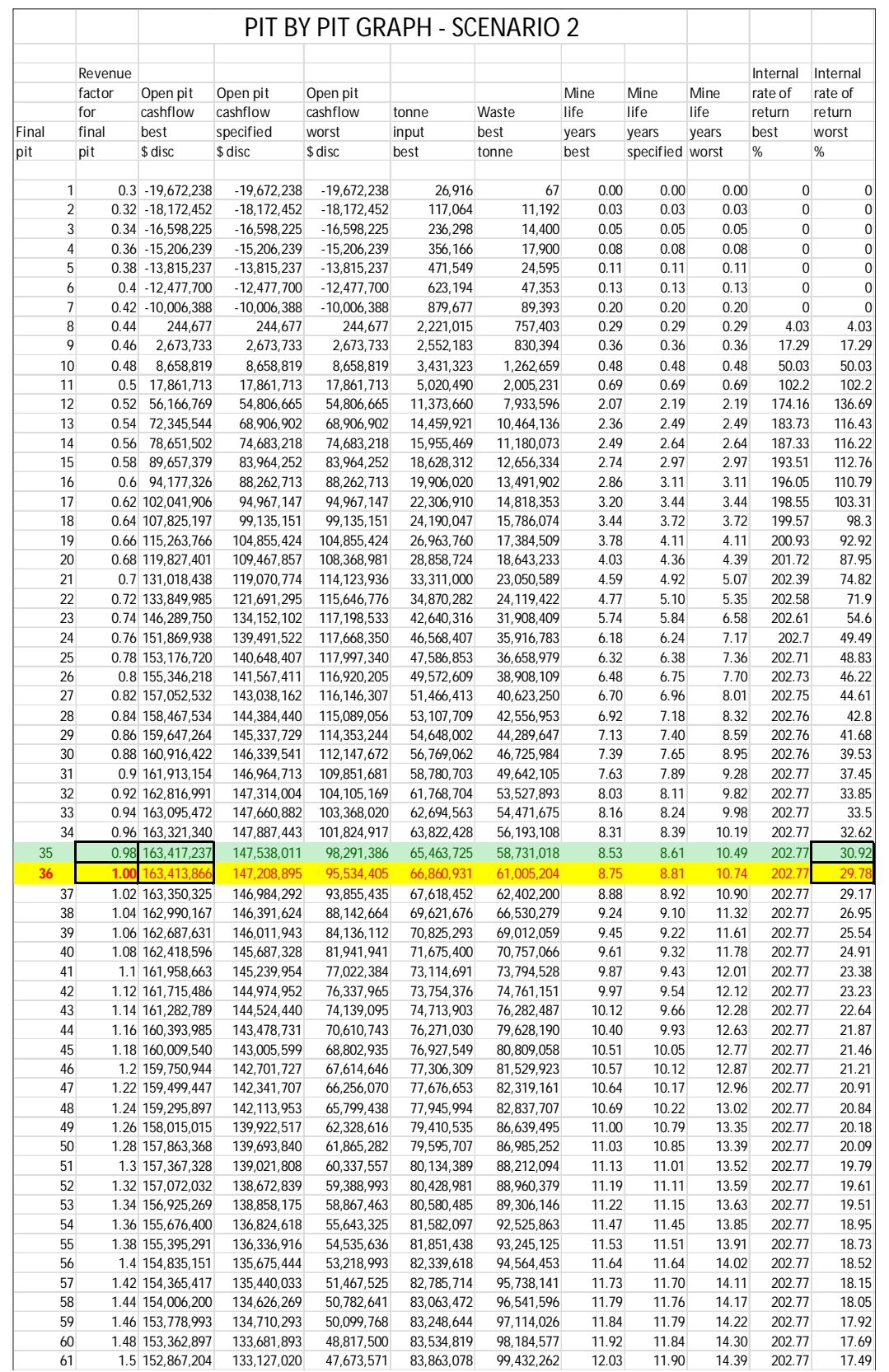




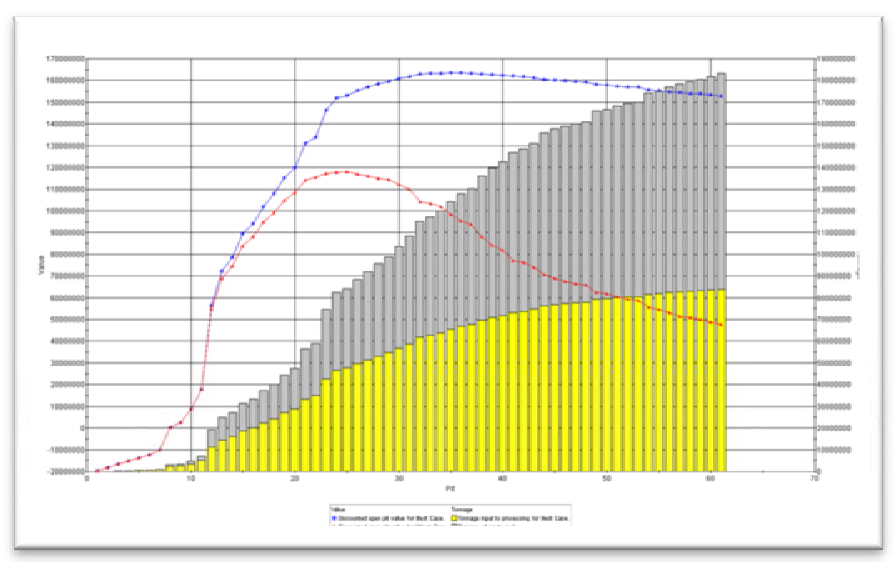

Sl. 5. Pit by Pit Graph optimizacije po Scenariju 2. - output Whittle Fx

Tabela 5. Dinamika otkopavanja po Scenariju 2.

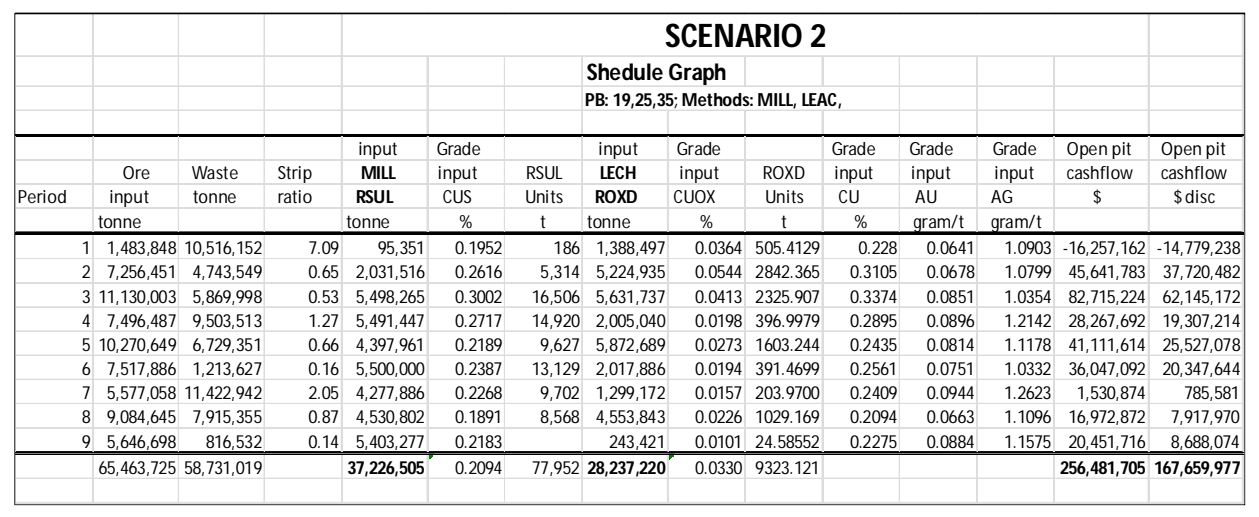

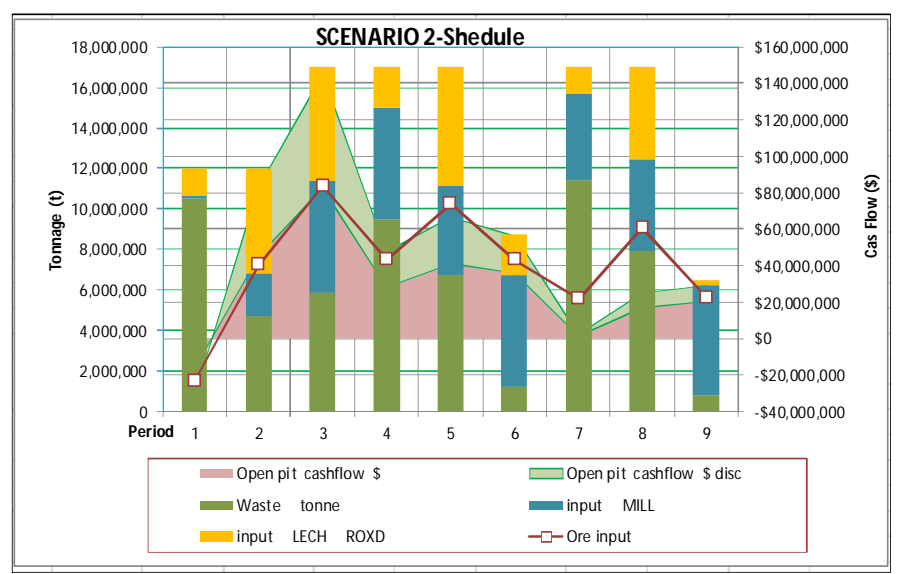

Sl. 6. Grafik dinamike otkopavanja po Scenariju 2-dve metode prerade MILL i LEAC, selektivno otkopavanje rude na kopu; 
SCENARIO 3. Dva tipa prerade MILL

(flotiranje) i LEAC (Heap leaching ) -

korišćenjem skladišta (Stock pile)

Tabela 6. Dinamika otkopavanja po Scenariju 3

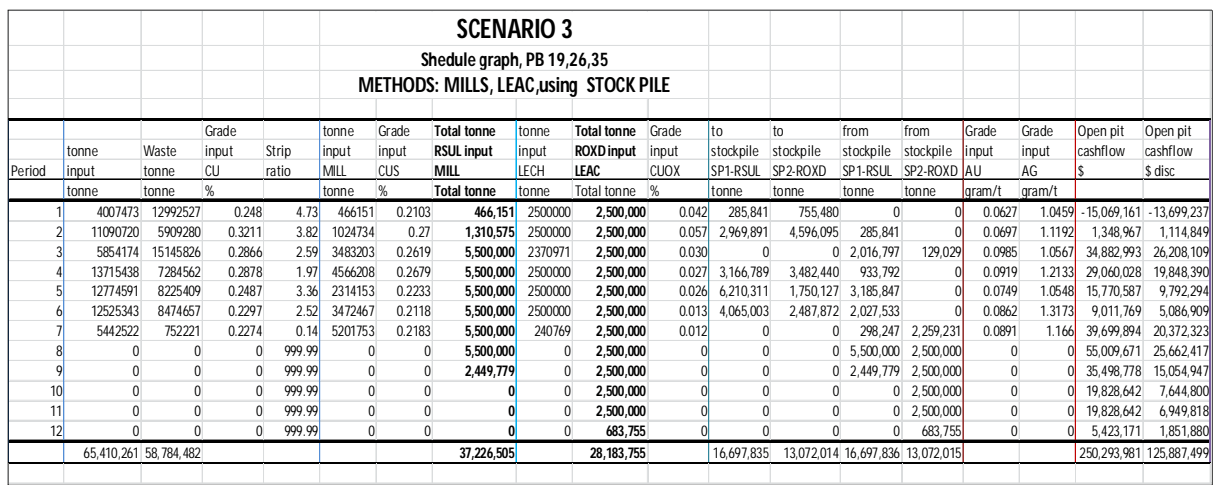

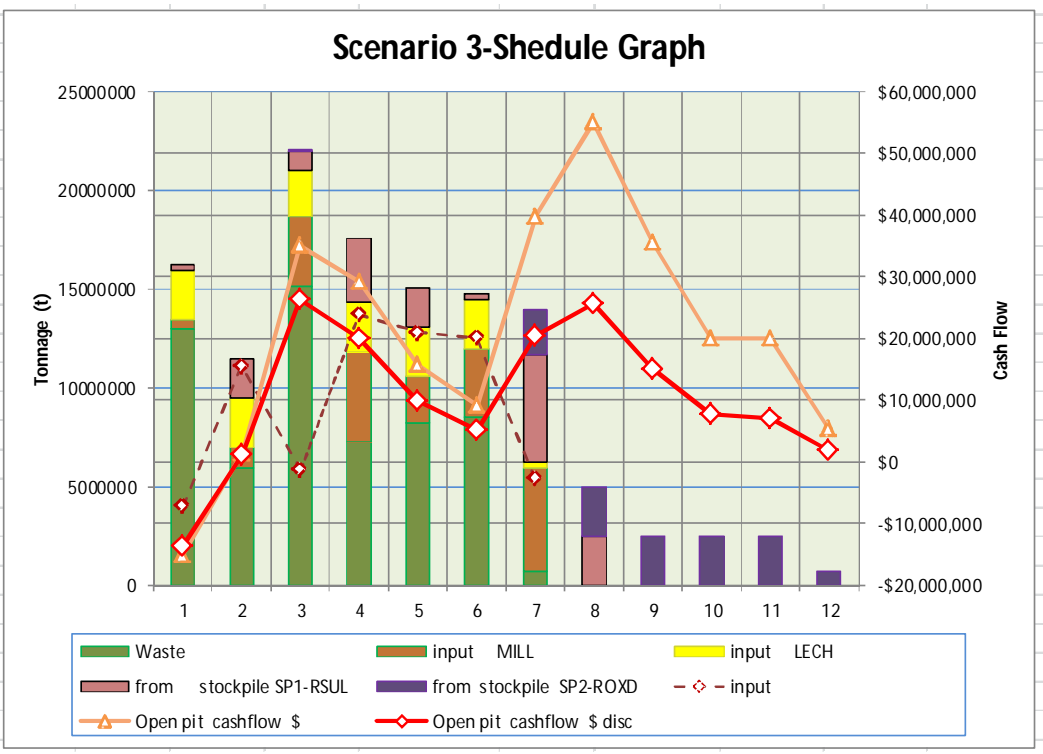

SI. 7. Grafik Dinamike otkopavanja po Scenariju 3 - dve metode prerade MILL i LEAC, selektivno otkopavanje rude na kopu;

\section{ZAKLJUČAK}

Dobijeni mogući kopovi iz procesa optimizacije (pit shells), za Revenu Factor $1^{3}$ (tj. prodajnu cenu tone $\mathrm{Cu}$ katode od $5000 \$$ ),

${ }^{3}$ Revenue Factor je koeficijent kojim se množi bazna prodajna cena metala. U slučaju ove međusobno se razlikuju za oko 8 miliona tona rude $\mathrm{u}$ korist kombinovane metode prerade, a količine $\mathrm{Cu}$ u rudi za 16,502. 44 t,

optimizacije bazna cena je $\$ 5000$, a RevFtr se kreće od 0.3 do 1.5 . 
dok je srednji sadržaj (had grade) u slučaju kombinacije metoda prerade veći za 3.27\%. Diskontovani novčani tok (Cash Flow) je veći za čak $61.94 \%$, što izraženo u novčanim jedinicama iznosi 47.905.712 \$.

Navedeni rezultati analize, i pored toga što je deo ulaznih podataka vezanih za luženje, solventnu ekstrakciju i elektrolizu - procenjeno na osnovu literature i iskus- tava u svetu, pa je stepen njihove tačnosti smanjen, ukazuju, principijelno, na značajna poboljšanja tehno - ekonomskih rezultata u slučaju korišćenja kombinovane metode prerade. To upućuje nato da je potrebno uraditi detaljnija ispitivanja (metallurgical test), čime će se povećati stepen tačnosti rezultata do nivoa relevantnosti za donošenje poslovnih odluka.

Tabela 7. Uporedni prikaz vrednosti novčanog toka (Cash Flow) za sva tri scenarija prerade

\begin{tabular}{|c|c|c|c|c|c|c|}
\hline \multirow{4}{*}{ Period } & \multicolumn{2}{|c|}{ Scenario 1} & \multicolumn{2}{|c|}{ Scenario 2} & \multicolumn{2}{|c|}{ Scenario 3} \\
\hline & Open pit & Open pit & Open pit & Open pit & Open pit & Open pit \\
\hline & cashflow & cashflow & cashflow & cashflow & cashflow & cashflow \\
\hline & $\$$ & \$disc & $\$$ & $\$$ disc & $\$$ & $\$$ disc \\
\hline 1 & $-9,847,862$ & $-8,952,602$ & $-16,257,162$ & $=14,779,238$ & "-15,069,161 & "-13,699,237 \\
\hline 2 & $-3,387,689$ & $-2,799,743$ & $45,641,783$ & $37,720,482$ & $1,348,967$ & $1,114,849$ \\
\hline 3 & $6,867,290$ & $5,159,496$ & $82,715,224$ & $62,145,172$ & $34,882,993$ & $26,208,109$ \\
\hline 4 & $3,452,064$ & $2,357,806$ & $28,267,692$ & $19,307,214$ & $29,060,028$ & $19,848,390$ \\
\hline 5 & $15,477,799$ & $9,610,495$ & $41,111,614$ & $25,527,078$ & $15,770,587$ & $9,792,294$ \\
\hline 6 & $20,814,587$ & $11,749,292$ & $36,047,092$ & $20,347,644$ & $9,011,769$ & $5,086,909$ \\
\hline 7 & $28,194,533$ & $14,468,253$ & $1,530,874$ & 785,581 & $39,699,894$ & $20,372,323$ \\
\hline 8 & $23,064,615$ & $10,759,813$ & $16,972,872$ & $7,917,970$ & $55,009,671$ & $25,662,417$ \\
\hline 9 & $21,474,074$ & $9,107,104$ & $20,451,716$ & $8,688,074$ & $35,498,778$ & $15,054,947$ \\
\hline 10 & $27,995,708$ & $10,793,557$ & 0 & 0 & $19,828,642$ & $7,644,800$ \\
\hline 11 & $28,542,461$ & $10,003,959$ & 0 & 0 & $19,828,642$ & $6,949,818$ \\
\hline 12 & $17,194,580$ & $5,724,357$ & 0 & 0 & $5,423,171$ & $1,851,880$ \\
\hline & $179,842,160$ & $77,981,787$ & $256,481,705$ & $167,659,977$ & $250,293,981$ & $125,887,499$ \\
\hline
\end{tabular}

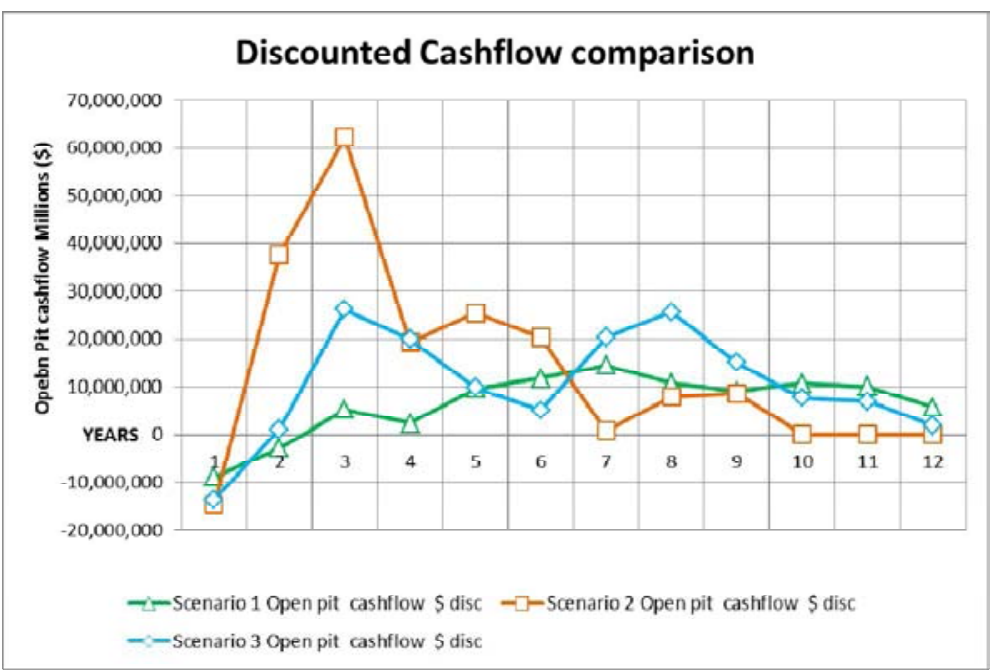

Sl. 8. Grafik uporednog prikaza Cash Flow za sva tri scenarija prerade 
Razlika u diskontovanom cashflow (zbirno i incremental po godinama) izmedju analiziranih scenarija 1. i 2. je značajna, dok između 2. i 3. nije prevelika, čak je u korist scenarija bez korišćenja stok pajlova, ali to može biti i posledica nedovoljnog poznavanja stvarnih tehno - ekonomskih parametara procesa luženja.

U ovoj analizi su korišćeni delom literaturni podaci o luženju [1,7], delom su vrednosti procenjene na osnovu drugih, tuđih iskustava ili zaključaka i poređenja sa pirometalurškim načinom prerade gde postoji dovoljno podataka. Naročito je bitno za luženje na gomili (Heap Leaching) utvrditi: iskorišćenja osnovnog i plemenitih metala, kao i vremena luženja, troškove same metode luženja od pripreme podloga za gomile rude koje će se tretirati, utroška kiseline, utroška folije za pripremu podloge, instalacije za razvod kiseline (cijanida) i drugih normativnih materijalakao i troškove dobijanja metala iz lužnih rastvora u metalurškom procesu prerade. Sve navedene troškove treba svesti na tonu rude, odnosno tonu finalnog proizvoda, na način kako softwer Whittle definiše i u analizi prihvata input troškova.

Autori članka nisu imali ambiciju da se u ovoj analizi bave samom tehnologijom luženja (detaljnom tehnikom i hemizmom procesa luženja) obzirom da su drugih specijalnosti, već da uporede ekonomske efekte za navedene slučajeve primenjenih metoda ekstrakcije osnovnog i pratećih plemenitih metala i na osnovu toga izvuku određene zaključke, prezentirane u radu.

Dosadašnje mišljenje dela stručne javnosti kao i stanovništva na lokalitetima rudnih ležišta - Cerovo Kraku Bugaresku, Ujova reka i drugih sadašnjih i potencijalnih lokaleta na kojima su ležišta sa sličnim karakteristikama, je da je postupak luženja vrlo rizičan po zaštitu životne sredine.Takvo mišljenje je demantovano u svetu, pored ostalog i time što se od ukupne svetske proizvodnje bakra, oko $20 \%$ dobija luže- njem. To rade $\mathrm{i}$ najrazvijenije države $u$ svetu, koje mnogo vise vode računa o zaštiti životne sredine nego mi, i čiji su propisi iz ove oblasti daleko strožiji od naših (SAD, Čile, Kanada, Južnoafrička Republika i dr.).

Svrha ove analize je da ukaže na potencijalnu, alternativnu metodu kojom se može uvećati dobit od eksploatacije ležišta koja sadrže povećani sadržaj oksidnih minerala $\mathrm{u}$ rudi koji negativno utiču na iskorišćenje metala pri flotacijskoj metodi obogaćivanja. Analiza ovog tipa čaki ako se radi o dilemi da li uopšte eksploatisati takva ležišta tj. da li je ekonomika eksploatacije zadovoljavajuća, o čemu postoje u ovdašnjoj stručnoj javnosti oprečna mišljenja, mogu dati odgovarajuće podatke za relevantnu kvalifikovanu ocenu i odluku.

Važno napomenuti i to da je trend tehnologije luženja - luženje i sulfidnih koncentrata.

\section{LITERATURA}

[1] J. Peacey ${ }^{1}$, G. Xian-Jian ${ }^{1}$, E. Robles ${ }^{2}$ : ,Copper Hydrometallurgy-Current Status, Preliminary Economics, Future Direction and Positioning Versus Smelting, J. Peacey ${ }^{1}$, GUO Xian-Jian ${ }^{1}$, E. Robles ${ }^{2,1}$ Hatch Associates Ltd., 2800 Speakman Drive, Mississauaga, Ontario L5K 2R7, Canada; ${ }^{2}$ Hatch IngenierosyConsultores Ltda., San Sebastian 283, Piso 9, Los Condes, Santiago 6760226, Chile;

[2] J. F. Lupo: Design and Operation of Heap Leach Pads, By: John F. Lupo, Ph.D. Golder Asociates;

[3] C. Avendaño Varas: Review on Heap Leaching of Copper Ores, Carlos Avendaño Varas, Chemical Engenieer, Sociedad Terral S.A;

[4] R. Denis, M. Marcotte: 1,7 Million Square Meters PVC Heap Leach Pad Case History,Robert Denis, Solmax International Inc., Varennes, Qc., 
Canada, Michel Marcotte, Genivar, Montreal, Qc., Canada, Draft paper submitted for publication GeoAfrica 2009;

[5] M. E. Orman, D. Romo, R. Tremayne: A Case Study of the Ocampo Phase 1 Heap Leach Expansion or Changing a Flat Pad to a Valley Fill, By: Marc E. Orman, David Romo, Russell Tremayne;

[6] Whittle Strategic Mine Planning, Gemcom Whittle ${ }^{\mathrm{TM}}$ Copyright (C) 2012 Gemcom Software International Inc.;
[7] G. Hovanec, Osvrt na osnovne ekonomske aspekte proizvodnje bakra primenom postupka kiselinskog luženja, Rudarski institut, Beograd;

[8] Z. Vaduvesković, M. Bugarin, D. Kržanović, Analiza kašnjenja u raskrivanju u odnosu na projektovani dugoročni plan otkopavanja na površinskom kopu Veliki Krivelj, Mining and Metallurgy Engineering Bor, 2/2013, str. 43-52.

[9] J. Vukašinović, J. Đorđević Boljanović, Rudarska industrija u ekonomiji znanja, Mining and Metallurgy Engineering Bor, 2/2013, str. 127-134.. 